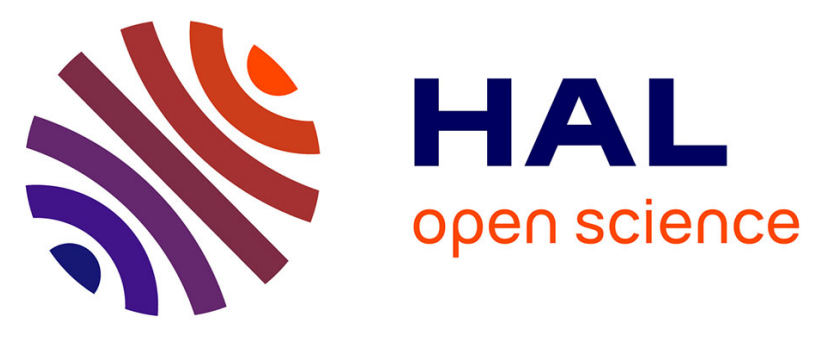

\title{
Sulfur diagenesis under rapid accumulation of organic-rich sediments in a marine mangrove from Guadeloupe (French West Indies)
}

Antoine Crémière, Harald Strauss, Mathieu Sebilo, Wei-Li Hong, Olivier Gros, Sabine Schmidt, Jennifer Tocny, Françoise Henry, Swanne Gontharet, Anniet M. Laverman

\section{To cite this version:}

Antoine Crémière, Harald Strauss, Mathieu Sebilo, Wei-Li Hong, Olivier Gros, et al.. Sulfur diagenesis under rapid accumulation of organic-rich sediments in a marine mangrove from Guadeloupe (French West Indies). Chemical Geology, 2017, 454, pp.67-79. 10.1016/j.chemgeo.2017.02.017 . hal-01507696

\section{HAL Id: hal-01507696}

https://hal-univ-rennes1.archives-ouvertes.fr/hal-01507696

Submitted on 4 Jul 2017

HAL is a multi-disciplinary open access archive for the deposit and dissemination of scientific research documents, whether they are published or not. The documents may come from teaching and research institutions in France or abroad, or from public or private research centers.
L'archive ouverte pluridisciplinaire HAL, est destinée au dépôt et à la diffusion de documents scientifiques de niveau recherche, publiés ou non, émanant des établissements d'enseignement et de recherche français ou étrangers, des laboratoires publics ou privés. 


\section{Sulfur diagenesis under rapid accumulation of organic-rich sediments in a marine mangrove from Guadeloupe (French West Indies)}

Antoine Crémière ${ }^{1,2,3^{*}}$, Harald Strauss ${ }^{4}$, Mathieu Sebilo ${ }^{1}$, Wei-Li Hong ${ }^{3}$, Olivier Gros ${ }^{5}$, Sabine Schmidt ${ }^{6}$, Jennifer Tocny ${ }^{5}$, Francoise Henry ${ }^{7}$, Swanne Gontharet ${ }^{7}$, Anniet M. Laverman $^{8}$

${ }^{1}$ Sorbonne Universités, UPMC Université Paris 06, CNRS, Institute of Ecology and Environmental Sciences (IEES), 4 place Jussieu 75005 Paris, France

${ }^{2}$ Geological Survey of Norway, 7491 Trondheim, Norway

${ }^{3}$ CAGE - Centre for Arctic Gas Hydrate, Environment and Climate, Department of Geology, UiT The Arctic University of Norway, Tromsø, Norway

${ }^{4}$ Institut für Geologie und Paläontologie, Westfälische Wilhelms-Universität Münster, Corrensstr. 24, 48149 Münster, Germany

${ }^{5}$ Institut de Biologie Paris-Seine, UMR 7138 - Evolution Paris-Seine, Equipe Biologie de la Mangrove. Université des Antilles, UFR des Sciences Exactes et Naturelles, Département de Biologie, BP 592. 97159 Pointe-à-Pitre cedex, Guadeloupe, France

${ }^{6}$ CNRS, EPOC, UMR 5805, Université de Bordeaux, F-33615 Pessac, France

${ }^{7}$ INSU-CNRS, UMR 8187, LOG, Laboratoire d'Océanologie et des Géosciences, Université Lille Nord de France COMUE, Université du Littoral-Côte d'Opale (ULCO), 32 avenue Foch, 62930 Wimereux, France

${ }^{8}$ Ecobio, UMR 6553, Université de Rennes 1, Campus de Beaulieu, 263 avenue du Général Leclerc, 35042 Rennes Cedex, France

\footnotetext{
* corresponding author: cremiere@caltech.edu. Present address: NASA Jet Propulsion Laboratory, 4800 Oak Grove Drive, Pasadena, CA 91109, USA. Phone: +18183545040 .
} 


\section{Abstract}

The biogeochemistry of sulfur and carbon during early-diagenetic processes within organicrich marine mangrove sediments was studied in the "Manche à Eau" lagoon, Guadeloupe, West Indies. These sediments are characterized by a total organic carbon content (TOC) mostly above 11 wt. $\%, \delta^{13} \mathrm{C}_{\mathrm{TOC}}$ below $-25 \%$ VPDB and $\mathrm{C} / \mathrm{N}_{\text {molar }}$ ratios exceeding 15 . Rates of mangrove-derived organic carbon accumulation vary between $\sim 200$ and $400 \mathrm{gOC} . \mathrm{m}^{-2} \cdot \mathrm{yr}^{-1}$, with highest rates at the shore of the lagoon. On the lagoon border, where colorless filamentous sulfur-oxidizing bacteria colonize the sediments, active sulfate reduction within the upper $20 \mathrm{~cm}$, with a net removal rate of $\sim 0.5 \mu \mathrm{mol} . \mathrm{cm}^{-3} \cdot \mathrm{d}^{-1}$, is assumed to be essentially driven by organic carbon oxidation. This is expressed by relatively low apparent sulfur isotope fractionation $\left({ }^{34} \varepsilon_{\text {net }}=-33 \%\right.$ ) and a gentle $\delta^{18} \mathrm{O} / \delta^{34} \mathrm{~S}_{\text {sulfate }}$ apparent slope of $0.36 \pm 0.03$ (2s). Further inside the lagoon, in the absence of sulfur-oxidizing bacteria, higher apparent sulfur isotope fractionation and a steeper $\delta^{18} \mathrm{O} / \delta^{34} \mathrm{~S}_{\text {sulfate }}$ slope $(0.67 \pm 0.20)$ suggest an overall lower sulfate removal rates that may be coupled to minor sulfur disproportionation. Spatial and vertical variation in sulfur cycling, reflected by oxygen and sulfur isotopic characteristics, seem to be mainly controlled by unsteady to relatively steady organic matter deposition and its reactivity. In all sediments, $\delta^{34} \mathrm{~S}$ values of pyrite are positively correlated with the TOC/TS ratio and negatively correlated with $\delta^{13} \mathrm{C}_{\mathrm{TOC}}$; suggesting a primary control of the quantity and quality of organic matter on the pyrite isotope records, despite potential iron-limiting conditions for the most active sites. Our results provide insights into the role of organic carbon input on sulfur cycling; stimulating sulfate reduction and in turn the presence of sulfur-oxidizing microbial mats, resulting in an intense cycling of both carbon and sulfur in these marine mangrove sediments. 
Keywords: microbial sulfate reduction, organic carbon-rich sediments, sulfur and oxygen isotopes, sulfur oxidizing microbial mats, early diagenesis, marine mangrove.

\section{Highlights}

- Elevated accumulation rates of mangrove-derived organic matter

- Heterogeneity of organic matter inputs affects sulfur cycle

- Quantity and quality of organic matter control sedimentary sulfide record 


\section{Introduction}

Under tropical and sub-tropical latitudes, mangroves are recognized as being among the most productive ecosystems at the sea-land interface. Mangroves are usually investigated on the terrestrial part, whereas studies regarding biology and geochemistry of the marine border, of this ecosystem are relatively scarce (Giri et al., 2011). Despite their relative restricted extent on Earth, the large amount of organic matter that is produced, buried and exported represents a significant component in the global carbon budget (e.g. Borges, 2003; Bouillon et al., 2008; Dittmar et al., 2006; Donato et al., 2011; Jennerjahn and Ittekkot, 2002; Kristensen et al., 2008). For instance, the stock of carbon in mangrove sediments has been estimated to range from 4 to $20 \mathrm{Pg}$ showing that they are among the most carbon-rich forest in the tropics (Donato et al., 2011).

Elevated accumulation of organic matter in sediments typically leads to anoxic conditions in subsurface sediments. Beneath the thin oxic layer, anaerobic organic matter remineralization covers a set of biogeochemical processes in which electron acceptors are typically sequentially used in order of energy yields as follow: $\mathrm{NO}_{3}{ }^{-}>\mathrm{Mn}^{+\mathrm{IV}}>\mathrm{Fe}^{+\mathrm{III}}>\mathrm{SO}_{4}{ }^{2-}$ ultimately followed by methanogenesis (Froelich et al., 1979). Due to its elevated concentration in brackish to marine environments, sulfate is a major electron acceptor for dissimilatory microbial sulfate reduction coupled to the oxidation of organic matter in subsurface sediment (Froelich et al., 1979; Jørgensen, 1982). Accordingly, sulfate reduction linked to organic carbon degradation, referred as organoclastic sulfate reduction (OSR) hereafter, can degrade a large proportion of sedimentary organic matter in respective marine mangrove sediments. OSR is mainly controlled by organic matter reactivity and quantity, sedimentation rate and depositional environment (e.g. Fike et al., 2015). A decrease in sulfatereduction rate with depth is typically observed in sediments due to an increase of refractivity of the residual organic matter (Jørgensen et al., 2010). At depths where sediments are free of 
sulfate, the methanogenic zone starts. Here, organic matter fermentation leads to the production of methane, which can diffuse up to sulfate-rich sediments. At the interface called sulfate-methane transition zone (SMTZ) where methane meets sulfate, methane can be oxidized together with the reduction of sulfate through the anaerobic oxidation of methane (AOM-SR), (Boetius et al., 2000; Reeburgh, 2007). Both OSR and AOM-SR potentially compete for the consumption of sulfate in sediments (Jørgensen et al., 2010). However, sulfate-driven $\mathrm{AOM}$ is a process generally assume to be restricted to a distinct horizon (SMTZ) whereas OSR occurs within the entire zone of sulfate reduction.

The metabolic pathway of sulfate reducers includes a succession of intracellular enzymatic transformations of sulfur intermediates (Peck, 1959, 1961). Each of these intracellular steps is assumed to be reversible implying that the cell-specific rate of sulfate reduction is the expression of the balance between the forward and backward fluxes (Brunner et al., 2005; Leavitt et al., 2013; Rees, 1973; Wing and Halevy, 2014). The preferential consumption of sulfate with lighter $\left({ }^{32} \mathrm{~S}\right)$ sulfur isotope during microbial sulfate reduction generates sulfide depleted in ${ }^{34} \mathrm{~S}$ whereas the residual sulfate becomes enriched in ${ }^{34} \mathrm{~S}$. This kinetic $\mathrm{S}$ isotope fractionation is affected by a series of environmental parameters such as ambient sulfate concentration, the source of organic carbon and temperature (Habicht and Canfield, 1997; Kaplan and Rittenberg, 1964; Leavitt et al., 2013; Sim et al., 2011; Wing and Halevy, 2014). Pure culture and environmental studies have highlighted an inverse relationship between SRR and sulfur isotopic fractionation (e.g Aharon and Fu, 2000; Wing and Halevy, 2014) where the decrease of SRR results in a rapid increase of the isotope fractionation value. Ultimately, this tends to reach the predicted thermodynamic equilibrium limit between sulfate and sulfide, that is, of $\sim 70-75 \%$ at $10-20{ }^{\circ} \mathrm{C}$ (Farquhar et al., 2003). Therefore, the isotopic signature of sulfur represents a relevant approach to understanding the 
biogeochemical sulfur cycle in marine sediments (e.g. Aharon and Fu, 2000; Aller et al., 2010; Pellerin et al., 2015; Raven et al., 2016; Rudnicki et al., 2001; Wortmann et al., 2001).

Hydrogen sulfide resulting from sulfate-reduction in anoxic sediments can react with reduced iron, either dissolved in the porewater or with reactive iron-rich minerals, and ultimately lead to the precipitation of diagenetically stable pyrite. Sequestration and burial of pyrite is the major sink in the cycling of sulfur and iron in marine sediments (Berner, 1984). In addition to burial, a large part of the hydrogen sulfide produced in anoxic sediment which is not permanently sequestered as pyrite, may be recycled (Thamdrup et al., 1994). Sulfide reoxidation to sulfate and/or to sulfur intermediates occurs mostly while hydrogen sulfide is diffusing into the upper suboxic-oxic interface. This is either mediated abiotically when hydrogen sulfide is reoxidized into elemental sulfur $\left(S^{0}\right)$ by reacting with iron or manganese oxide-hydroxides (Böttcher et al., 2001; Canfield, 1989; Holmkvist et al., 2011; Yao and Millero, 1996) or by biotic reactions, e.g. sulfur-oxidizing bacteria using $\mathrm{O}_{2}$ or $\mathrm{NO}_{3}{ }^{-}$as an electron acceptor (Fossing et al., 1995). The production of hydrogen sulfide can lead to the development of sulfur-oxidizing bacteria forming dense microbial mats of filamentous colorless bacteria covering the sediment. The presence of these microbial mats, with sulfur oxidizers belonging to Beggiatoacae, has been observed in various environments from deep sea to shallow water marine environments (Grünke et al., 2011; Jean et al., 2015; McKay et al., 2012).

The geochemistry of sulfur has been investigated in mangrove sediments showing the importance of OSR in the degradation of organic matter and of sequestration of sulfide as pyrite (Holmer et al., 1994; Kristensen et al., 2008; Lallier-Verges et al., 1998). However, study in iron-poor sediments showed that up to $\sim 50 \%$ of the organically bound sulfur could be from a diagenetic origin (Canfield et al., 1998). Moreover, sulfur reoxidation through disproportionation of elemental sulfur (Pellerin et al., 2015) or with iron oxyhydroxide- 
hydroxides reduction (Aller et al., 2010; Madrid et al., 2006) may also significantly contribute to the recycling of sulfur. Large differences are expected between different mangrove sites since the dynamic of sulfur cycling appears to be highly variable due in part to the unsteady nature of these environments (Aller et al., 2010).

The main objective of this work is to investigate the coupling between carbon and sulfur cycles as controlled by sulfate reduction and the resulting sedimentary pyrite record in organic-rich marine mangrove sediments from the "Manche à Eau" lagoon (Guadeloupe, French West Indies). Elevated and variable organic matter supply in mangrove sediments (Kristensen et al., 2008) most likely results in spatial variation in sulfate reduction rates. We hypothesize that the presence (or absence) of the sulfur-oxidizing mats recently described by Jean et al. (2015) is due to $\mathrm{H}_{2} \mathrm{~S}$ production from active sulfate reduction, driven by organic matter supply. In order to study carbon-sulfur dynamic, sedimentary and porewater sulfur geochemistry was characterized in sediments covered with microbial mats and compared to sediments lacking sulfur oxidizers. In addition, sediment carbon composition and sediment accumulation rates were determined. Finally, porewater sulfate profiles were modeled to constrain net sulfate removal rates (SRR). The heterogeneity of organic matter supply in mangrove sediments makes this a unique environment for studying the imprint of microbial sulfur cycling during diagenesis and their potential impact on the C-S-Fe biogeochemical cycles.

\section{Material and Methods}

\subsection{Study site}

The "Manche à Eau" lagoon is a part of the mangrove area edging the Grand Cul-de-Sac and is located in the Northeastern part of Basse-Terre (Fig. 1a), the western island of Guadeloupe, French West Indies. The lagoon is surrounded by a dense forest of Rhizophora 
mangle species (Fig. 1b). The marine sediment close to the roots of Rhizophora mangle is covered by patchy white microbial mats (Fig. 1c) composed predominantly by filamentous colorless bacteria belonging to the family Beggiatoaceae (Jean et al., 2015) as well as a small fraction of filamentous cyanobacteria (Guidi-Rontani et al., 2014). Microelectrode measurements in these sediments showed that oxygen is depleted in the first few millimeters (Jean et al., 2015), thus sedimentary organic carbon degradation processes can be considered to be mostly in the suboxic to anoxic realm.

\subsection{Sampling}

Push-cores were collected in April 2013 at 3 different locations (16²16'33" N latitude and $61^{\circ} 33^{\prime} 18^{\prime \prime} \mathrm{W}$ longitude, $\sim 50 \mathrm{~cm}$ water depth, Fig. 1d). Two cores (\#1 and 2), with 35 and $40 \mathrm{~cm}$ of sediment recovery, respectively, were sampled at 2 different sites right below mangrove trees at the edge of the lagoon. Both were characterized by the presence of white microbial mats close to the sediment-water interface whereas the third core, $(\# 3,25 \mathrm{~cm}$ recovery) was collected $\sim 1$ meter further inside the lagoon where the microbial mats are visually always absent. The penetration of all cores was limited by the presence of a biodetrital carbonate-rich layer at depth (Gontharet et al., 2016). The upper $\sim 20 \mathrm{~cm}$ of the two cores with the microbial mats were black peat-like sediments and turned to dark brown sediment below $20 \mathrm{~cm}$. This dark brown color is similar to the one observed in the sediment core without the microbial mat. Cores were directly brought back to the laboratory, where porewater was extracted using the Rhizon sampling technique. The sediments were sliced into $1-2 \mathrm{~cm}$ intervals and frozen at $-20^{\circ} \mathrm{C}$ prior to further subsampling and analyses. Depths of the sediment intervals were corrected from sediments compaction during porewater extraction. Porewater samples from the microbial mats showed a distinct yellowish color, which was not observed in the core without microbial mat. 


\subsection{Sediment composition}

Sediments were freeze-dried prior to analysis. The same sample, homogenized by crushing, was used for elemental and total organic carbon stable isotope analyses. Sediments were decarbonated $(1 \mathrm{M} \mathrm{HCl})$, rinsed two times with distilled water and dried at $40^{\circ} \mathrm{C}$ overnight. These decarbonated samples were analyzed for total organic carbon (TOC), total nitrogen (TN) and total sulfur (TS) contents by elemental analysis (Elementar Vario EL III). All data are reported in weight \% (wt. \%), except for $\mathrm{C} / \mathrm{N}$, which is expressed as molar ratios. Uncertainties are 0.02 wt. $\%$ for TN, 0.14 wt. $\%$ for TOC and 0.34 wt. $\%$ for TS. Decarbonated sediments were thermally decomposed to $\mathrm{CO}_{2}$ and carbon isotope ratios of the TOC $\left(\delta^{13} \mathrm{C}_{\mathrm{TOC}}\right)$ were determined by Elemental Analyzer (Elementar) coupled to a continuous flow IRMS (Isoprime). The reference used was tyrosine $\left(\delta^{13} \mathrm{C}=-23.2 \%\right.$ VPDB), a laboratory standard calibrated against Vienna PeeDee Belemnite (VPDB). Isotope data are expressed in per mil using the conventional delta notation $\left(\delta^{13} \mathrm{C}\right)$ relative to VPDB. Analytical precision is about $\pm 0.1 \%$ for $\delta^{13} \mathrm{C}$.

Total Fe concentrations (TFe) were determined in about $20 \mathrm{mg}$ dried and grounded bulk sediments, digested twice with a mixture of 3mL HF 22.6 M (Suprapur Merck) and 1mL $\mathrm{HNO}_{3} 14.6 \mathrm{M}$ (sub-boiling, Merck) at $125^{\circ} \mathrm{C}$ for $48 \mathrm{~h}$. Samples were then digested with $3 \mathrm{~mL}$ $\mathrm{HCl} 6 \mathrm{M}$ (sub-boiling, Merck) and $1.5 \mathrm{~mL} \mathrm{HNO}_{3} 14.6 \mathrm{M}$ (sub-boiling, Merck) at $125{ }^{\circ} \mathrm{C}$ for 48 h. After evaporation, samples were diluted into $2 \% \mathrm{HNO}_{3}$, filtered using polyethylene syringes equipped with cellulose acetate filter $(0.2 \mu \mathrm{m})$. Analyses were performed by inductively coupled plasma-optical emission spectrometry (ICP-OES, VARIAN Vista Pro, axial view). For quality assurance, reagents blanks, sample replicates and standard reference materials (MESS-3 and PACS-2, National Research Council Canada) were used to assess the accuracy and precision of the analyses. Mean recovery for total Fe was $110 \pm 5 \%$ for the two reference materials. 
Scanning electron microscopy (SEM) coupled with an energy dispersive X-ray spectrometer was performed on particles collected from sieved sediments.

\section{4. ${ }^{210} \mathrm{~Pb}$ dating and rates of organic carbon accumulation}

Sediment accumulation rates were determined using the ${ }^{210} \mathrm{~Pb}$ method, which is based on the excess of ${ }^{210} \mathrm{~Pb}\left({ }^{210} \mathrm{~Pb} \mathrm{xs}\right)$ being rapidly incorporated in the sediment from atmospheric fallout and water column scavenging (Appleby, 2001). In the sediment column, ${ }^{210} \mathrm{~Pb}_{\mathrm{xs}}$ decays with depth, equivalent to time, according to its half-live $\left(\mathrm{T}_{1 / 2}=22.3\right.$ years $)$. In contrast, ${ }^{137} \mathrm{Cs}$ $\left(T_{1 / 2}=30\right.$ years $)$ is an artificial radionuclide; its occurrence in the environment is primarily the result of the nuclear weapon test fall-out in the early sixties.

${ }^{210} \mathrm{~Pb},{ }^{226} \mathrm{Ra}$ and ${ }^{137} \mathrm{Cs}$ activities were measured on dry sediments by non-destructive gamma spectrometry using a low background, high efficiency, well-shaped $\gamma$ detector (CANBERRA) (Schmidt and Deckker, 2015). Calibration of the $\gamma$ detector was achieved using certified reference material (IAEA-RGU-1, IAEA-RGTh and IAEA-135). Activities were expressed in mBq. $\mathrm{g}^{-1}$ and errors were based on 1 standard deviation counting statistics. Excess ${ }^{210} \mathrm{~Pb}\left({ }^{210} \mathrm{~Pb}\right.$ xs $)$ was calculated by subtracting the activity supported by its parent isotopes, ${ }^{226} \mathrm{Ra}$, from the total ${ }^{210} \mathrm{~Pb}$ activities in the sediment.

Sediment water content was measured twice for each depth by drying $5 \mathrm{~cm}^{3}$ of wet sediment at $40^{\circ} \mathrm{C}$. Sediment porosity was calculated for a dry-bulk density of $2.8 \mathrm{~g} . \mathrm{cm}^{-3}$. Results can be found in Supplementary Fig. 1. Integrated rates of organic carbon accumulation were conservatively calculated following Müller and Suess (1979) and are shown in Table 2.

\subsection{Sulfur and oxygen isotope analyses in porewater and sediment}

Directly upon sampling, porewater samples were directly stabilized in a $10 \% \mathrm{Zn}$-acetate solution to prevent $\mathrm{H}_{2} \mathrm{~S}$ oxidation. Samples were kept frozen prior to their preparation for 
stable isotope analyses of sulfate and $\mathrm{H}_{2} \mathrm{~S}$. Porewater samples were centrifuged and the $\mathrm{ZnS}$ precipitate was filtered, rinsed with MilliQ water and transformed to silver sulfide $\left(\mathrm{AgS}_{2}\right)$ by the addition of $0.1 \mathrm{M} \mathrm{AgNO}_{3}$ solution. Silver sulfide precipitates were rinsed with $5 \%$ ammonium hydroxide solution followed by deionized water. The supernatant containing dissolved sulfate was acidified to $\mathrm{pH} \sim 2(\mathrm{HCl} 25 \%)$, heated and $8.5 \% \mathrm{BaCl}_{2}$ solution was added at subboiling conditions in order to precipitate barium sulfate $\left(\mathrm{BaSO}_{4}\right)$. Thereafter, the solution was kept at $80^{\circ} \mathrm{C}$ for 3 hours. Sulfate concentration was determined gravimetrically from the $\mathrm{BaSO}_{4}$ precipitate. The $\mathrm{AgS}_{2}$ and $\mathrm{BaSO}_{4}$ precipitates were dried at $75^{\circ} \mathrm{C}$ for 24 hours.

The sulfide content in the sediment was determined by using approximately $500 \mathrm{mg}$ crushed bulk sediment for a sequential wet chemical extraction of sulfide sulfur applying the chromous chloride technique (Canfield et al., 1986). In short, this consist of an initial treatment with $20 \mathrm{~mL}$ of $\mathrm{HCl}(25 \%)$ for one hour should liberating acid-volatile sulfide (AVS), which was not observed during the extractions. This was followed by letting the sample react with $30 \mathrm{~mL}$ of $1 \mathrm{M} \mathrm{Cr}(\mathrm{II}) \mathrm{Cl}_{2}$-solution for 2 hours at $85{ }^{\circ} \mathrm{C}$ in order to liberate pyrite sulfur. Sulfide was liberated as hydrogen sulfide that was captured in a $3 \%$ zinc acetate solution and subsequently transformed into a silver sulfide precipitate by adding $15 \mathrm{~mL}$ of 0.1 $\mathrm{N} \mathrm{AgNO}_{3}$-solution. The silver sulfide was subsequently filtered, rinsed with $5 \%$ ammonium hydroxide solution followed by deionized water and placed in a drying oven at $75^{\circ} \mathrm{C}$ overnight.

Sulfur isotope measurements were conducted on $200 \mu \mathrm{g}$ of $\mathrm{Ag}_{2} \mathrm{~S}$ or $\mathrm{BaSO}_{4}$, which was homogenously mixed with $300-600 \mu \mathrm{g}$ of $\mathrm{V}_{2} \mathrm{O}_{5}$ and placed into a tin cup. Isotope measurements were performed using a ThermoFinnigan Delta Plus interfaced with a Carlo Erba elemental analyzer (EA-IRMS). For oxygen isotope measurements, $200 \mu \mathrm{g}$ of barium sulfate precipitate was placed into a silver cup. Isotope measurements were performed using a ThermoFinnigan Delta Plus XL connected to a high-temperature pyrolysis unit (TC/EA- 
IRMS). Isotopic compositions are reported in conventional $\delta$ units relative Vienna Canyon Diablo Troilite (VCDT) for $\delta^{34} \mathrm{~S}$ and relative to Vienna Standard Mean Ocean Water (VSMOW) for $\delta^{18} \mathrm{O}$ values. All samples were run in duplicate and samples were re-run when deviation above $0.5 \%$ between both results was detected. Analytical performance was monitored with international reference materials (IAEA S1; $\delta^{34} \mathrm{~S}=-0.35 \pm 0.11, \mathrm{~S} 2 ; \delta^{34} \mathrm{~S}=$ $21.47 \pm 0.11, \mathrm{~S} 3 ; \delta^{34} \mathrm{~S}=-31.35 \pm 0.07, \mathrm{SO}-5 ; \delta^{18} \mathrm{O}=12.01 \pm 0.30, \mathrm{SO}-6 ; \delta^{18} \mathrm{O}=-11.35 \pm$ 0.28 , NBS $\left.127 ; \delta^{18} \mathrm{O}=8.61 \pm 0.31\right)$ and in-house lab standards $\left(\delta^{34} \mathrm{~S}=2.46 \pm 0.16\right.$ and $\delta^{18} \mathrm{O}=$ $12.42 \pm 0.39)$. The analytical reproducibility for $\delta^{34} \mathrm{~S}$ and $\delta^{18} \mathrm{O}$ values are better than $\pm 0.3 \%$ and $\pm 0.5 \%$, respectively.

\subsection{Modelling net sulfate reduction rates}

Two different models to investigate the dominant biogeochemical reactions and quantify the reaction rates were applied. Steady-state modeling was performed on cores 1 and 2, a modeling strategy that is both easy to implement and robust in results. We considered a mass balance of the sulfate concentration as well as its sulfur isotopic signature to estimate the net rates of OSR and AOM-SR. For the site with non-steady state condition (Core 3), we developed a kinetic model to investigate the key factors, such as organic matter input, sedimentation rate, and solute flux that affect the rates of sulfate turnover. The framework and assumptions of the two models are described below. The detailed mathematical formulation and the parameters used in both models are provided in the Supplementary material.

The fundamental principle for our steady state model is mass balance. For cores 1 and 2, the sulfate concentration decreases with depth in a smooth $2^{\text {nd }}$-order polynomial fashion (Fig. 5). Such trend in porewater profile indicates that, for every given depth, the input flux from the shallower depth is greater than the output flux to the deeper depth. The difference between input and output fluxes represents the overall net sulfate removal rate, both by OSR and/or 
AOM-SR, under steady state condition. We assigned three different OSR modes: a constant OSR rate until the depth of sulfate depletion (the "constant-k" mode), a linearly decrease of the OSR rate with depth (the "variable-k" mode), and an exponential decrease of the OSR rate following the expression proposed by Middelburg (1989) (the "Middelburg" mode). We further assumed that the difference between the overall sulfate reduction rate and the assumed OSR rate is then equals to the AOM-SR rate. The same mass balance principle was applied on both ${ }^{32} \mathrm{~S}_{\text {sulfate }}$ and ${ }^{34} \mathrm{~S}_{\text {sulfate }}$ concentrations; the $\delta^{34} \mathrm{~S}_{\text {sulfate }}$ profiles therefore serve as a constraint for the estimated proportion of AOM-SR and OSR. We assumed a rate-dependent sulfur isotopic fractionation following the relationship proposed by Dale et al. (2009). The OSR mode that provides the best-fit results with $\delta^{34} \mathrm{~S}_{\text {sulfate }}$ profiles was then chosen for rate estimation.

For the kinetic model, we assumed a system with eight primary dissolved species (sulfate, methane, hydrogen sulfide, ammonium, phosphate, chloride, bicarbonate, and sodium) and one solid species (organic matter) to account for the species of interest and achieve charge balance in the fluid. We will only focus on sulfate profiles in our discussion when deciding the most likely scenario. We considered diffusion of sulfate, burial of organic matter over time and sulfate, and OSR. We simulated diffusion and OSR with CrunchFlow, a Fortran routine developed by Steefel (2009). We simulated burial of solid and dissolved species separately with a customized MATLAB routine. Such modeling strategy is adopted to overcome the numerical issue in CrunchFlow as detailed in Hong et al., (2016). We simulated several scenarios considering different sedimentation modes. The basic model framework and additional sensitivity tests were included in the Supplementary material. The different scenarios we modeled are described in the Results section. 


\section{Results}

\subsection{Sediment composition}

Visual observations indicate that the surface of the sediments covered by the white microbial mats, in contrast to the sediment without the mat, contains Rhizophora mangle leaves and roots (Fig. 1). The sediment geochemistry of these two cores is similar whereas the sediments taken further inside the lagoon without microbial mats, differ (Fig. 2 and Table 1). Overall, the sedimentary TOC and TN contents range from 4.9 to $18.8 \mathrm{wt}$. $\%$ and from 0.3 to 1.4 wt. $\%$, respectively. In all three cores, TOC and TN contents decrease with depth whereas $\mathrm{C} / \mathrm{N}$ molar ratios increase with values ranging between 15.1 and 20.1 . The $\delta^{13} \mathrm{C}_{\mathrm{TOC}}$ values also increase with depth and vary between -26.2 to $-24.4 \%$ VPDB. Total sulfur contents are relatively constant (average $4.6 \pm 0.3$ wt. $\%, n=16$ ) in cores 1 and 2 whereas it decreases from 5.9 to 2.5 wt. $\%$ below $5 \mathrm{~cm}$ in core 3 . Total iron content varies between 3.5 and 5.8 wt. \% and is relatively constant through depth. Abundant pyrite, sometimes surrounded by an organic film, is observed at all depths and in all the sediments cores (Fig. 3). Crystal morphology includes framboidal aggregates and euhedral to subhedral octahedric and cubic crystals. Typical crystal sizes range from less than $1 \mu \mathrm{m}$ to $\sim 5 \mu \mathrm{m}$.

\subsection{Sediment accumulation rates and dating}

Surface ${ }^{210} \mathrm{~Pb}$ excess activities $\left({ }^{210} \mathrm{~Pb}_{\mathrm{xs}}\right)$ range from 90 (Core 2$)$ to 127 (Core 3$) \mathrm{mBq} \mathrm{g}^{-1}$. ${ }^{210} \mathrm{~Pb}_{\mathrm{xs}}$ decreases downcore according to the radioactive decay of ${ }^{210} \mathrm{~Pb}$ with time (Fig. 4). There are still significant levels of excess at the base of the cores: e.g. about $32 \mathrm{mBq} \mathrm{g}^{-1}$ at 35 $\mathrm{cm}$ in Core 2. According to the CF:CS (constant flux: constant sedimentation model), the sediment accumulation rates (SAR) in cores 2 and 3 are similar, $1.0 \mathrm{~cm} \mathrm{y}^{-1}$, with slightly lower rate in Core $1\left(0.91 \mathrm{~cm} \mathrm{y}^{-1}\right)$. According to the extrapolated ${ }^{210} \mathrm{~Pb}_{\mathrm{xs}}$-derived age, sediment at the core basis corresponds to an age of about 1976 year in Core $1(35 \mathrm{~cm}), 1974$ 
year in Core $2(40 \mathrm{~cm})$ and 1989 year in Core $3(25 \mathrm{~cm})$. The timescales encompassed in the three cores is too short to observe ${ }^{137} \mathrm{Cs}$ peak activities associated to nuclear weapon test fallout (max. in 1963).

\subsection{Porewater and sulfur geochemistry}

In the sediments colonized by microbial mats, sulfate concentrations decreased from 27.5 $\mathrm{mM}$ in the overlying waters, to $2.4 \mathrm{mM}$ in porewaters at $20 \mathrm{~cm}$ with similar patterns (Fig. 5). Below $20 \mathrm{~cm}$, sulfate is not completely depleted and shows concentrations ranging from 0.1 to $2.4 \mathrm{mM}$ (Table 2). The sediment outside the microbial mats coverage (Core 3 ) has a different sulfate porewater profile with concentrations slightly decreasing down to $20 \mathrm{mM}$ in the top $5 \mathrm{~cm}$ and then increasing to $\sim 24 \mathrm{mM}$ below $5 \mathrm{~cm}$. For all the three cores, the $\delta^{34} \mathrm{~S}$ and $\delta^{18} \mathrm{O}$ values of sulfate increased with depth and reaching a maximum $\delta^{34} \mathrm{~S}$ value of $90 \%$ and

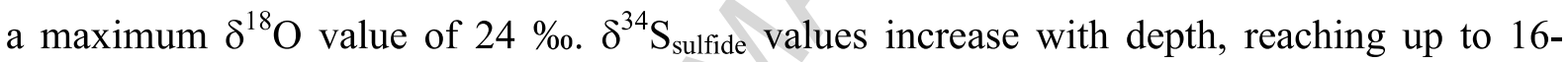
$17 \%$ in cores 1 and 2 , in contrast, $\delta^{34} \mathrm{~S}_{\text {sulfide }}$ is decreasing from $-8 \%$ in the first $\mathrm{cm}$ to $-24 \%$ in Core 3. Except for the surface sediments, $\delta^{34} \mathrm{~S}$ values of pyrite essentially decrease with depth from -6 to $-23 \%$ in Cores 1 and 2 and from -22 to $-26 \%$ in Core 3 .

\subsection{Model results}

As shown in Figure 6, all models successfully reproduce the observed isotopic profile until the depth of sulfate depletion. Fractionation factors applied to each biogeochemical reaction can be found in Supplementary Materials. The "constant k" mode results in a constant OSR rate through depth whereas the "variable k" and "Middelburg" modes predict a decrease of OSR rate through depth compensated by an increase of AOM-SR rate. The estimated OSR rates range from 100 to $720 \mathrm{mmol} \cdot \mathrm{m}^{-2} \cdot \mathrm{yr}^{-1}$ and AOM-SR rates at the SMTZ (i.e. $20 \mathrm{~cm}$ ) range from 360 to $975 \mathrm{mmol} \cdot \mathrm{m}^{-2} \cdot \mathrm{yr}^{-1}$. 
To explain the potential non-steady state porewater sulfate profile in core 3 , we applied a transport-reaction model on the sulfate profile of this site and considered four different scenarios. In the first two scenarios, we assigned steady deposition of organic matter from sediment-water interface for 25 years. Different rate constants for OSR were assigned to reflect different reactivity of the organic matter. Neither of these scenarios reproduce the observed sulfate concentration profile (Fig. 7). For the third scenario, we initiated the model with a profile of decreasing sulfate content by using the outcome from scenario 2 . In scenario 3, labile organic matter starts to deposit half way (12.5 years) during the simulation. Organic matter older than 12.5 years was assumed to be totally refractive and therefore consumes no sulfate. This input of labile organic matter stimulates OSR and consumes sulfate in porewater. This scenario (3) represents a period of time with elevated input of labile organic matter to the mangrove, such as during a period with more precipitation. In the last scenario (4), a 5-cm thick labile organic matter is deposited instantaneously while the rest of organic matter was considered refractive under the time scale we modeled. OSR was rapidly induced by this sudden input of labile organic matter. This scenario implies that stimulation of OSR happened recently, such as a couple months, so that diffusion did not have time to smooth the profile. Such estimation of time scale is however too short considering the sedimentation rate in the core ( $1 \mathrm{~cm}$ per year). The discrepancy can be explained by:

(1) The relatively poorly-constrained tortuosity value used in the model as what was assigned is only a first-order estimation. A higher tortuosity will result in slower diffusion and therefore longer time estimated by the model.

(2) The sedimentation rates estimated from the cores were averages over some time span that may not be able to capture abrupt sedimentation or mixing events. The sampling resolution for ${ }^{210} \mathrm{~Pb}$ is about $\sim 10 \mathrm{~cm}$ which cannot differentiate a steady sedimentation over this $10 \mathrm{~cm}$ or an abrupt event followed by a long no-sedimentation period. 
Nonetheless, our model results confirm the non-steady state nature of the fluid system in these cores and provide a first order temporal constraint given the uncertainties involved. The last scenario (\#4) provides the best fit results to our observed sulfate profile from Core 3 . We therefore conclude this is the most likely scenario happened at this location.

\section{Discussion}

\subsection{Source and accumulation of organic-rich sediments}

Elevated organic carbon and nitrogen contents in the top layers (TOC> $12 \mathrm{wt} \%$ and TN $>1$ wt. \%, Fig. 2 and Table 1) at all sampling sites indicate a high input of organic-rich material, typical for mangrove sediments (Kristensen et al., 2008; Lallier-Verges et al., 1998). Low $\delta^{13} \mathrm{C}_{\mathrm{TOC}}$ values, mostly below $-25 \%$, together with $\mathrm{C} / \mathrm{N}$ ratios between 15 and 20 suggest that the dominant source of organic matter is derived from $\mathrm{C}_{3}$ land plants (Fig. 8, Lamb et al., 2006 and references therein). The sedimentary organic matter likely originates from the dense vegetation of Rhizophora mangle trees surrounding the lagoon and includes a great proportion of leaves and root litter (Fig. 1).

All cores show similar ${ }^{210} \mathrm{~Pb}$-derived accumulation rates, ranging between 0.9 and 1.0 $\mathrm{cm} . \mathrm{yr}^{-1}$, corresponding to the upper range of rates reported in other mangrove sediments (Breithaupt et al., 2012). Almost constant ${ }^{210} \mathrm{~Pb}_{\mathrm{xs}}$ in the top $10 \mathrm{~cm}$ of Core 1 may be attributed to a mixed layer. The initial deposition of these sediments started 20 to 40 years ago broadly corresponding to 1989's hurricane Hugo that heavily affected the mangrove forest in this area (Imbert et al., 1996). Calculated apparent accumulation rates of organic carbon are among the highest values reported for mangrove sediments (Breithaupt et al., 2012), with depthintegrated values of $386 \pm 79$ and $396 \pm 111$ gOC.m $\mathrm{m}^{-2} \cdot \mathrm{yr}^{-1}$ for cores with a microbial mats coverage, but decrease down to $199 \pm 35$ gOC. $\mathrm{m}^{-2} \cdot \mathrm{yr}^{-1}$ outside the microbial mats site, denoting a decrease of organic carbon sequestration towards the inner part of the lagoon. 
Mangrove root systems are known to affect the deposition of organic matter by preventing its dispersion and consequently allowing higher organic matter accumulation rates in the vicinity of mangrove roots (Furukawa et al., 1997; Gontharet et al., 2016). At these sites from the edge of mangrove trees, TOC and TN contents decrease with depth whereas $\delta^{13} \mathrm{C}_{\mathrm{TOC}}$ and $\mathrm{C} / \mathrm{N}$ increase, likely reflecting an increase of mangrove-derived organic matter deposition over time as a consequence of the root system development, preventing organic matter dispersion, and the seaward progression of mangrove trees on the lagoon.

Lower TOC content and higher $\delta^{13} \mathrm{C}_{\mathrm{TOC}}$ values, compared to the microbial mats covered sediments, were observed in the bare sediment, indicating a slightly higher contribution of marine organic matter, similar to what has been previously observed in other mangrove sediments (Bouillon et al., 2003; Sanders et al., 2014). This marine source can include algae and phytoplankton produced in the lagoon itself, but may also originate from allochthonous organic matter carried by marine inwelling as one third of the lagoon water is renewed daily by tides (Mantran et al., 2009). Such variability in composition over less than 2 meters (i.e. sampling distance between cores 1 and 3 ) highlights the heterogeneity of the sedimentary substrate controlled by the inputs of organic-rich material. Nevertheless, it is consistent with the position of this core collected further away from the mangrove trees.

\subsection{Controls on sulfate reduction}

Where microbial mats cover the sediments, sulfate profiles show a characteristic decrease in concentration within the upper $20 \mathrm{~cm}$ of sediment (Fig. 5). The slightly concave-down shape of the sulfate concentration profile (Fig. 6) is typically attributed to a system dominated by organic matter degradation coupled with continuous sulfate reduction through depth (e.g. Berner, 1980; Borowski et al., 1999). The substantial input of fresh and reactive organic matter from mangrove vegetation most likely drives microbial sulfate reduction coupled to sedimentary organic carbon oxidation (i.e., OSR) (Jørgensen, 1982) as follows: 


$$
2 \mathrm{CH}_{2} \mathrm{O}+\mathrm{SO}_{4}{ }^{2-} \rightarrow 2 \mathrm{HCO}_{3}{ }^{-}+\mathrm{HS}^{-}
$$

In steady-state environments with relatively low to moderate organic matter load, it is generally assumed that, due to substrate competition with sulfate reducers, methanogenesis is restricted to sulfate-depleted sediments whereas AOM-SR occurs at the sulfate-methane transition located at the base of the zone of sulfate reduction (Dale et al., 2008; Oremland and Polcin, 1982):

$$
\mathrm{CH}_{4}+\mathrm{SO}_{4}{ }^{2-} \rightarrow \mathrm{HCO}_{3}^{-}+\mathrm{HS}^{-}+\mathrm{H}_{2} \mathrm{O}
$$

However, in such organic-rich sediments, methanogens can use non-competitive substrates resulting in simultaneously OSR and methanogenesis within sulfate-rich sediments (Chuang et al., 2016; Holmer and Kristensen, 1994; Maltby et al., 2016; Oremland et al., 1982). Supposing that this is the case, part of the sulfate consumption within the upper $20 \mathrm{~cm}$ may be attributed to AOM coupled to sulfate reduction. Without methane concentration measurements, it is difficult to unequivocally assess the role of AOM in sulfate reduction. Nevertheless, preliminary results suggest the absence of specific biomarkers for both methanotrophy and methanogenesis in these sediments (N. Chevalier, personal communication). To estimate the extent to which sulfate reduction coupled to AOM may be responsible for sulfate consumption, the rates of net sulfate removal were modelled with different approaches on organic matter reactivity (Fig. 6). It has to be highlighted that our modelled rates of sulfate removal represent the sum of sulfate reduction and reoxidative processes, implying that the actual microbial sulfate reduction rates may be overestimated. Supported by the preliminary biomarker results, we favor the "constant k" mode where AOMSR may be confined at $\sim 20 \mathrm{~cm}$ (Fig. 6) and predicts that only $\sim 6 \%$ of the total net depthintegrated sulfate removal might be attributed to AOM-SR.

The coincidence of sulfate concentration decrease and relative high TOC content $(\sim 14$ wt. \%) in the upper $5 \mathrm{~cm}$ of the non-microbial-mat-covered core suggests that active sulfate 
reduction was stimulated by the recent (several months to years) input of organic-rich sediment (Fig. 2 and 7). The increase in sulfate concentration at depth results from the unsteady nature of the mangrove environment that is potentially controlled by a change in organic matter input and reactivity over time. Lower organic matter content $(<10 \mathrm{wt}$. \%) exhibiting a higher $\delta^{13} \mathrm{C}_{\mathrm{TOC}}$ at greater depth in this sediment indicates that organic matter may be more refractory to OSR in agreement with our unsteady modelling approach (Fig. 7).

\subsection{Isotopic constraints on the porewater sulfur isotopes}

The observed increase in $\delta^{34} \mathrm{~S}_{\text {sulfate }}$ values, concomitant with a decreasing sulfate concentration, is consistent with preferential consumption of ${ }^{32} \mathrm{~S}_{\text {sulfate }}$ through active microbial sulfate reduction (e.g. Habicht and Canfield, 1997; Kaplan and Rittenberg, 1964). The extreme enrichment of $\delta^{34} \mathrm{~S}_{\text {sulfate }}$ up to $90 \%$ at depth is reflecting an apparent difference in the sulfur isotopic composition between sulfate and sulfide reaching -74 \%o (Fig. 5). This large isotopic difference, observed at low sulfate concentrations, potentially reflects Rayleigh distillation effects, as depicted in Fig. 10 , where the $\delta^{34} \mathrm{~S}_{\text {sulfate }}$ exponentially increase as sulfate reduction propagates whereas sulfide tends to reach the initial composition of sulfate (e.g. Goldhaber and Kaplan, 1980). Another possibility would be that a higher isotopic fractionation occurs at $20 \mathrm{~cm}$ imparted by low rates of AOM-SR (Deusner et al., 2014; Weber et al., 2016).

Assuming a steady-state situation for the upper $20 \mathrm{~cm}$ below microbial mats, the transport-reaction model predicts an apparent sulfur isotopic fraction factor of $-33 \%$. Due to their unsteady regime, the same approach cannot be applied to the sediment without microbial mat. Since the upper $5 \mathrm{~cm}$ of this core presents some similarities with the two others, it can be argued that a relatively similar apparent fractionation may be expected whereas deeper (below $5 \mathrm{~cm}$ ), the apparent fractionation is likely higher. As mentioned previously, this change with 
depth is, at least partly, due to the change in source and reactivity of the organic matter inputs through time (Fig. 2), as electron donor availability is known to strongly affect both SRR and the fractionation factor (Leavitt et al., 2013; Sim et al., 2011). The fact that the sulfate concentrations increase below $5 \mathrm{~cm}$ despite the relatively significant amount of remaining organic matter (TOC $>4$ wt. \%) may also be interpreted as indicative of other processes that are influencing sulfur cycling in the deeper part of the core. Since input of sulfate by groundwater discharges seems to be unlikely as no mixing trend is discernable (Fig. 9) and constant chloride concentrations through depth suggest the absence of lateral freshwater inflow (see Supplementary Fig. 2), the role of superimposed sulfur reoxidative processes may also account for the observed isotopic signatures (see after).

\subsection{Sulfate sulfur-oxygen isotopes relationship}

Similar to sulfur, sulfate-reducing bacteria kinetically fractionate sulfate oxygen with light $\left({ }^{16} \mathrm{O}\right)$ isotopes being used more efficiently. As a result, the composition of the remaining sulfate pool becomes enriched in ${ }^{18} \mathrm{O}$. Nevertheless, intracellular intermediate sulfur compounds, such as sulfite $\left(\mathrm{SO}_{3}{ }^{2-}\right)$, can exchange oxygen isotopes with water in the bacterial cell leading to a change in the oxygen isotope composition of the residual porewater sulfate in case these intermediates are completely reoxidized back to sulfate and released into the surrounding porewater (Antler et al., 2013; Brunner et al., 2005). The implications of such a difference between sulfur and oxygen metabolization is that the study of relative changes of the sulfur and oxygen isotope compositions of the residual sulfate may provide information regarding the intracellular recycling of sulfur intermediates (Antler et al., 2013; Brunner et al., 2005).

It has been proposed that the slope of $\delta^{18} \mathrm{O}$ against $\delta^{34} \mathrm{~S}$ of sulfate is directly linked to the SRR with a steeper slope (i.e. $\delta^{18} \mathrm{O}$ increasing faster than $\delta^{34} \mathrm{~S}$ does) corresponding to a slower SRR which in turn, is the expression of an increase in the reoxidation of sulfur intermediates 
(Aharon and Fu, 2000; Antler et al., 2013; Böttcher et al., 1998, 1999; Brunner et al., 2005). Antler et al. (2014) suggested that OSR in organic-poor sediments and AOM coupled to SR produced distinct $\delta^{18} \mathrm{O}-\delta^{34} \mathrm{~S}_{\text {sulfate }}$ patterns due to difference in microbial mechanisms. A data compilation by Antler et al. (2015) further showed that in sedimentary environments where methane is in excess, AOM coupled to sulfate reduction results in a characteristic $\delta^{18} \mathrm{O}-\delta^{34} \mathrm{~S}$ slope of sulfate confined around 0.37. A similar value of $0.36 \pm 0.03\left(r^{2}=0.93\right)$, in agreement with fast rate of sulfate reduction, is discernible for both cores below the microbial mats (Fig. 10, excluding the 2 samples below $20 \mathrm{~cm}$ where isotopic equilibrium with water oxygen isotopes is reached). If our hypothesis that sulfate reduction is mostly driven by organic matter oxidation is true, our data would indicate that this proposed "AOM fingerprint" may also be produced via high SRR mostly driven by organo-clastic sulfate reduction in highly reactive organic-rich sediments.

The two deepest samples with $\delta^{34} \mathrm{~S}$ of sulfate above $75 \%$ (Fig. 10) show a remarkable asymptotic tendency toward the apparent $\delta^{18} \mathrm{O}$ thermodynamic equilibrium with seawater (Aller et al., 2010; Antler et al., 2013; Turchyn et al., 2006). Moreover, the apparent isotopic difference between sulfide and sulfate is up to $-74 \%$, that is close to the expected equilibrium value (Farquhar et al., 2008). Both sulfur and oxygen reaching equilibria are likely the result of a combination of kinetic isotope effects and Rayleigh distillation under fast rate of sulfate reduction rather than thermodynamic equilibrium reached at slow rates of sulfate reduction.

In contrast, a steeper $\delta^{18} \mathrm{O}-\delta^{34} \mathrm{~S}_{\text {sulfate }}$ slope for sediments without microbial mats of $0.67 \pm$ $0.20\left(r^{2}=0.71\right)$ indicates that oxygen isotopes increase faster than sulfur isotopes. This can be interpreted as a slower SRR and higher back flux of equilibrated intracellular oxygen isotopes between sulfate and seawater (Antler et al., 2013; Böttcher et al., 1999, 1998; Brunner et al., 2005). This slope decreases down to $0.60\left(r^{2}=1\right)$ for the upper $5 \mathrm{~cm}$, sustaining the assumption of higher sulfate reduction rates associated with organic-rich sediments in the upper part of 
the sediment column. Accordingly, the scattering of $\delta^{18} \mathrm{O}-\delta^{34} \mathrm{~S}_{\text {sulfate }}$ reflects the presence of variable SRR that may be combined with a higher contribution of disproportionation relative to SRR at depth (Böttcher et al., 2001).

\subsection{Oxidative processes in the sulfur cycle}

The processes involved in sulfide oxidation are subtle and frequently superimposed on sulfate reduction (Aller et al., 2010; Canfield and Thamdrup, 1994; Howarth and Jørgensen, 1984; Pellerin et al., 2015). Sulfide can either be completely oxidized all the way to sulfate or to sulfur intermediates (i.e. sulfite, thiosulfate and elemental sulfur) that can disproportionate into sulfate and sulfide (Böttcher et al., 2001; Canfield and Thamdrup, 1994; Thamdrup et al., 1993).

Abiotic and chemoautotrophic sulfide oxidation with oxygen is generally limited to the sediment-water interface. In sediments close to the mangrove edge where elevated sulfate reduction sustains the presence of microbial mats, oxidation of upward diffusing sulfide is mediated, in part, by sulfur-oxidizing Beggiatoa close to the sediment-water interface or even slightly above within the water column (Jean et al., 2015). Additionally, the aerial root systems of Rhizophora mangle transporting oxygen into the sulfidic rhizosphere (e.g. McKee et al., 1988) may reoxidize sulfide at depth accounting for less ${ }^{34}$ S-enriched values of sulfate below $15 \mathrm{~cm}$ along with the remaining low sulfate concentration (from 0.1 to $2.4 \mathrm{mM}$ ).

The elevated iron content measured in all sites $(4.9 \pm 0.6$ wt. \%) whereas Mn content is two orders of magnitude lower, led us to hypothesize that reactive Fe species such as Fe(III)oxide-hydroxides may also be involved in the re-oxidation of sulfide. Below the oxygenated subsurface sediments, iron oxides are known to act as an efficient barrier oxidizing sulfide essentially into elemental sulfur $\left(S^{0}\right)$ (Böttcher et al., 2001; Thamdrup et al., 1993), which can subsequently be disproportionated by chemoautotrophic bacteria (Böttcher et al., 2001; Thamdrup et al., 1993). 
In sediments covered by microbial mats, the elevated porewater sulfide concentrations $(>$ $7 \mathrm{mM}$, Jean et al., 2015) would typically result in lower disproportionation rates or even its inhibition (Canfield and Thamdrup, 1996; Thamdrup et al., 1993) implying that elemental sulfur and other sulfur intermediates would accumulate in porewater. This hypothesis is consistent with the observed yellowish color of porewater. Thus, it seems that sulfate reduction dominates the sulfur biogeochemical cycle in these sites.

In the sediments that are not colonized by sulfur-oxidizing bacteria, the sulfide gradient is likely less pronounced and $\mathrm{Fe}(\mathrm{III})$ oxyhydroxides may play a more important role in recycling sulfur through disproportionation along with regulating the sulfide flux though iron sulfide formation (Habicht and Canfield, 2001). Whereas oxidation of sulfide into sulfur intermediates has relatively small $(<5 \%$ ) isotope effects (e.g. Chambers and Trudinger, 1979; Fry et al., 1988; Fry and Hayes, 1984; Zerkle et al., 2009), the disproportionation of $\mathrm{S}^{0}$ leads to sulfate that is enriched in ${ }^{34} \mathrm{~S}$ from +11 to $+35 \%$ whereas sulfide is depleted in ${ }^{34} \mathrm{~S}$ down to -9\%o (Böttcher et al., 2001, 2005; Canfield and Thamdrup, 1994). Moreover, oxygen presumably derived from water is transferred into sulfate with an enrichment factor of +17 to $+21 \%$ (Böttcher et al., 2001, 2005). Accordingly, molecules of sulfate produced by disproportionation of elemental sulfur having a hypothetical $\delta^{34} \mathrm{~S}$ value similar to dissolved sulfide (i.e. $-25 \%$ ), would have a $\delta^{18} \mathrm{O}$ value of $\sim 19 \%$ and $\delta^{34} \mathrm{~S}$ values ranging from -14 to $+10 \%$. The implication of this theoretical calculation suggests that disproportionation is not the main source of sulfate at depth (i.e. below $10 \mathrm{~cm}$ ) as these predicted $\delta^{34} \mathrm{~S}$ sulfate values differ from the measured ones. Importantly, paired $\delta^{18} \mathrm{O}-\delta^{34} \mathrm{~S}_{\text {sulfate }}$ are not sufficient to differentiate whether the residual sulfate is only affected by slower sulfate reduction or that a minor amount of disproportionated sulfate also accounts for the observed isotope compositions. 


\subsection{The sedimentary sulfide record}

Porewater data depict the ongoing sulfur biogeochemistry, whereas a more integrated picture is recorded in sedimentary sulfides. The formation of pyrite occurs by several reactive schemes through metastable iron sulfide intermediates such as greigite or mackinawite (Berner, 1984; Rickard, 1997; Wilkin and Barnes, 1996). Owing to the low sulfur isotope fractionation $(<1 \%$, Price and Shieh, 1979) between dissolved sulfide and precipitating sulfide minerals, the sulfur isotopic composition of dissolved sulfide is assumed to be captured in pyrite. Availability of iron, controlling where sulfide minerals form, and SRR, affecting the degree of $\mathrm{S}$ isotopic discrimination, are known to exert control on the $\delta^{34} \mathrm{~S}$ value of pyrite (e.g. Canfield, 2001; Fike et al., 2015).

Several lines of evidence suggest that sedimentary pyrite is present in great amount. This includes elevated total iron and sulfur (Fig. 11a), XRD analyses (Gontharet et al., 2016) and abundant pyrite framboids observed under SEM (Fig. 3). We acknowledge the fact that a part of iron is carried by poorly reactive minerals (e.g. silicates) (Canfield et al., 1992) whereas sulfur is incorporated into organic compounds (Sinninghe Damste and De Leeuw, 1990). Iron availability limiting pyrite formation in cores below microbial mats is apparently reflected by the TOC/TS ratio above 2.6 (Fig. 11b) whereas in sediments without microbial mats a linear correlation between TOC and TS can be observed. This line shows a TOC/TS ratio classical for marine sediments $(2.8 \pm 0.8$, Berner and Raiswell, 1983) suggesting that the TOC content controls the amount of pyrite with relatively lower concentrations of TOC limiting sulfide production and thus pyrite formation. In contrast, elevated SRRs in sediments below microbial mats produce excess of sulfide and pyrite formation is hypothetically limited by the availability of reactive iron. Under these iron-limiting conditions, dissolved sulfide diffuses to the sediment-water interface where most of the reductive dissolution of iron oxidehydroxides occurs resulting in early pyrite formation close to the seafloor presenting lower 
$\delta^{34} \mathrm{~S}$ values compared to pyrite formed deeper in the sediments under progressive iron reduction. This process is apparently recorded in the upper $5 \mathrm{~cm}$ where the increase in pyrite $\delta^{34} \mathrm{~S}$ values (3-7 \%o) could reflect at least two generations of pyrite; a first that precipitated in the vicinity of the seawater-sediment interface with low $\delta^{34} \mathrm{~S}$ values $(\sim-15 \%)$ and a second that formed below (at around $5 \mathrm{~cm}$ ) where the early $\delta^{34} \mathrm{~S}_{\text {pyrite }}$ is overprinted by higher $\delta^{34} \mathrm{~S}$ values (>-5\%). Multiple generation of pyrite during early burial is also consistent with the various crystal morphologies observed under SEM (Fig. 3).

The isotopic composition of sedimentary pyrite forming at the seafloor is, however, significantly depleted in ${ }^{34} \mathrm{~S}$ relative to dissolved sulfide with an isotopic difference of up to $13 \%$ (Fig. 5). Offsets between porewater and sedimentary sulfides have been classically interpreted as a result of ${ }^{34} \mathrm{~S}$-depleted sulfide produced through disproportionation (Canfield and Thamdrup, 1994; Habicht and Canfield, 1997). Alternatively, it was recently proposed that in the Santa Barbara basin, pyrite is a direct product of microbial sulfate reduction close to the seafloor where it precipitates within microenvironments such as biofilms or microbial aggregates (Raven et al., 2016). Assuming that subsurface of the core is undisturbed, the first model would imply that the early generation of sedimentary sulfides precipitate rapidly at the sediment water-interface (at least shallower than the first porewater sample) from low $\delta^{34} \mathrm{~S}$ $\mathrm{H}_{2} \mathrm{~S}$ values. The second model requires elemental $\mathrm{S}$ having the same $\delta^{34} \mathrm{~S}$ values as pyrite (Raven et al., 2016), this could be in our case induced by sulfur-oxidizing Beggiatoa sp. as they have been shown to store elemental S within the cytoplasmic granules (Jean et al., 2015). Similar to Raven et al., (2016), the pyrite is also draped by organic films (Fig. 3) supporting the concept of their intracellular formation. Although our data may accommodate with both models, we note that the decoupling of $\delta^{34} \mathrm{~S}$ values between pyrite and dissolve sulfide seems to be favored in organic-rich sediments and iron-limited environment (Fig. 5). 
Overall, all sediment cores show a net decrease in $\delta^{34} \mathrm{~S}$ of pyrite with depth, which cannot be explained by a late diagenetic pyrite overprint mentioned above. Remarkably, the linear trend between $\delta^{34} \mathrm{~S}$ of pyrite and TOC/TS (Fig. 12) suggests that the isotopic composition of pyrite is mainly controlled by the amount of organic matter relative to the sulfur content in the sediments, whereas the negative correlation of $\delta^{34} \mathrm{~S}_{\text {pyrite }}$ with $\delta^{13} \mathrm{C}_{\mathrm{TOC}}$ may highlight the influence of source and reactivity of organic matter on the isotopic composition recorded in pyrite. Thus, it is proposed that the amount and reactivity of organic matter supplied exerts a major control on the isotopic composition of pyrite and that the recorded isotopic discrimination imparted by sulfate reducers as sedimentary sulfide is primarily controlled by changes in the depositional environment.

\section{Conclusion}

Contrasting modes of sulfur diagenesis are observed over a short distance in mangrove sediments which appear to be essentially controlled by the heterogeneity in organic matter inputs over short geological timescale. At the edge of the lagoon, mangrove trees sustain high accumulation of fresh and reactive organic-rich sediments. The resulting elevated sulfate removal rates are interpreted to be mostly coupled to organic matter oxidation, although this hypothesis requires to be further tested. Elevated rates of sulfate removal are reflected in porewater geochemistry by relatively small apparent sulfur fractionation $\left({ }^{34} \varepsilon_{\text {net }}=-33 \%\right.$, a remarkably gentle $\delta^{18} \mathrm{O}-\delta^{34} \mathrm{~S}_{\text {sulfate }}$ slope $(\sim 0.36)$ and $\mathrm{S}$ and $\mathrm{O}$ isotopes of sulfate approaching the thermodynamic equilibrium fractionations in the deeper part of the cores.

Further inside the lagoon, where the sediments are not colonized by colorless sulfuroxidizing bacteria, relatively lower organic carbon accumulation rates are observed leading to an overall less pronounced sulfate reduction, higher sulfur isotopic discrimination and steeper $\delta^{18} \mathrm{O}-\delta^{34} \mathrm{~S}_{\text {sulfate }}$ slope. The unsteady nature of these sediments is reflected in the upper part of 
the core where rates of sulfate reduction were stimulated by higher inputs of organic matter over the last 5 years. Moreover, it cannot be ruled out that elemental sulfur, generated by reduction of iron oxide-hydroxides and its subsequent disproportionation to sulfate may affect ${ }^{18} \mathrm{O}-\delta^{34} \mathrm{~S}$ of sulfate at depth. In this regard, the analysis of minor $\mathrm{S}$ isotopes $\left({ }^{33} \mathrm{~S}\right.$ and $\left.{ }^{36} \mathrm{~S}\right)$ could provide an insightful tool for identifying processes involved in the reoxidation of sulfur species (e.g. Johnston et al., 2005; Kunzmann et al., 2017; Pellerin et al., 2015; Zerkle et al., 2016).

The relationships between $\delta^{34} \mathrm{~S}$ values recorded in pyrite and TS/TOC as well as $\delta^{13} \mathrm{C}_{\mathrm{TOC}}$ highlight a significant control of organic matter deposition and reactivity on the sedimentary record. Altogether, these results provide a comprehensive approach of the dynamic sedimentary sulfur cycle controlled by organic matter input heterogeneity both in space and (short) time in mangrove sediments. Our findings may help in understanding the nature of sulfur isotopic records preserved in sediments deposited throughout the Earth history. 


\section{Figures}

Fig. 1 (a) Location map of the "Manche à Eau" lagoon in the Guadeloupe Island. (b) Rhizophora mangle mangrove trees surrounding the lagoon. (c) Mangrove tree roots and patchy white microbial mats mostly consisting in sulfur-oxidizing Beggiatoa sp. that colonize the sediment. (d) Black-peat like sediment core collected below mangrove trees.

Fig. 2 Sedimentary profiles of total organic carbon (TOC) and its isotopic composition $\left(\delta^{13} \mathrm{C}_{\mathrm{TOC}}\right)$, total nitrogen $(\mathrm{TN}), \mathrm{C} / \mathrm{N}$ molar ratio, total sulfur $(\mathrm{TS})$ and total iron $(\mathrm{TFe})$. Data from sediments below sulfur-oxidizing Beggiatoa microbial mats(at the edge of lagoon) are shown in red whereas blue symbols indicate sediment sampled further inside $(\sim 1 \mathrm{~m})$ the lagoon where microbial matsare absent.

Fig. 3 Examples of backscattered electron (BSE) images of pyrite associated with carbonate (a) and with ligneous fragment (b). Note that most of the pyrite clusters seem to be covered with a thin organic layer. Scale bars are $10 \mu \mathrm{m}$.

Fig. 4 Excess of ${ }^{210} \mathrm{~Pb}\left({ }^{210} \mathrm{~Pb}_{\mathrm{xs}}\right)$ in sediments and calculated sedimentation rates.

Fig. 5 Porewater concentration of sulfate $\left(\mathrm{SO}_{4}{ }^{2-}\right)$ and its sulfur and oxygen isotopic compositions $\left(\delta^{34} \mathrm{~S}_{-} \mathrm{SO}_{4}{ }^{2-}\right.$ and $\left.\delta^{18} \mathrm{O}-\mathrm{SO}_{4}{ }^{2-}\right)$, hydrogen sulfide and pyrite sulfur isotopic compositions $\left(\delta^{34} \mathrm{~S}-\mathrm{H}_{2} \mathrm{~S}\right.$ and $\delta^{34} \mathrm{~S}$-Pyrite $)$ and sulfur isotope difference between $\mathrm{H}_{2} \mathrm{~S}$ and $\mathrm{SO}_{4}{ }^{2-}$ $\left(\Delta^{34} \mathrm{~S}\right)$. The shaded areas represent the apparent thermodynamic equilibrium for $\delta^{18} \mathrm{O}$ and $\delta^{34} \mathrm{~S}$, respectively. Data from sediments below sulfur-oxidizing Beggiatoa microbial mats (at the edge of lagoon) are shown in red whereas blue symbols indicate sediment sampled further inside $(\sim 1 \mathrm{~m})$ the lagoon where microbial mats are absent.

Fig. 6 Steady state models of the net sulfate removal rates for sediments below microbial mats. The three models; constant $\mathrm{k}$, variable $\mathrm{k}$ and Middelburg represent different assumptions on organic matter reactivity but all can reproduce the $\delta^{34} \mathrm{~S}$ value of sulfate. The total modelled 
rate of net sulfate removal is shown in black. Sulfate removal rates attributed to anaerobic oxidation of methane (AOM-SR) and organoclastic sulfate reduction (OSR-SR) are shown in green and red, respectively.

Fig. 7 Non-steady state model of the net sulfate removal rates for the sediment outside microbial mats. Scenario 4 is the best-fit scenario. The four different scenarios are described in the "Results" section 2.6 and detailed in Supplementary materials.

Fig. 8 Origin of sedimentary organic matter as indicated by $\delta^{13} \mathrm{C}_{\mathrm{TOC}}$ against TOC/TN (molar ratio). Fields are defined from the compilation of coastal sediments by Lamb et al. (2006). The range of $\delta^{13} \mathrm{C}_{\mathrm{TOC}}$ values measured in sediments colonized by Rhizophora mangles close to the study area are presented in grey for comparison (Lallier-Verges et al., 1998). Data from sediments below sulfur-oxidizing Beggiatoa microbial mats (at the edge of lagoon) are shown in red whereas blue symbols indicate sediment sampled further inside $(\sim 1 \mathrm{~m})$ the lagoon where microbial mats are absent.

Fig. $9 \delta^{18} \mathrm{O}$ against $\delta^{34} \mathrm{~S}$ of porewater sulfate. The line is a linear correlation for sediments below the microbial mats (red symbols, $\delta^{34} \mathrm{~S}-\delta^{18} \mathrm{O}_{\text {sulfate }}$ slope of 0.36 ) typical for high sulfate reduction rates whereas the concave shape (dashed curve) depicts the evolution of $\delta^{18} \mathrm{O}$ against $\delta^{34} \mathrm{~S}$ at low rates of sulfate reduction (see Antler et al., 2013). The shaded area represents oxygen isotopic equilibrium between sulfate and water. Data from sediments below sulfur-oxidizing Beggiatoa microbial mats (at the edge of lagoon) are shown in red whereas blue symbols indicate sediment sampled further inside $(\sim 1 \mathrm{~m})$ the lagoon where microbial mats are absent.

Fig. $10 \delta^{34} \mathrm{~S}$ of porewater sulfate and sulfide as a function of the relative fraction of remaining sulfate concentration. Examples showing "idealized" Rayleigh distillation effects (closed system) are depicted with black curves. Note that this simplified model does not account for 
transport of solutes and differs from the transport-reaction used to estimate the fraction factor (see Fig. 7). Data from sediments below sulfur-oxidizing Beggiatoa microbial mats (at the edge of lagoon) are shown in red whereas blue symbols indicate sediment sampled further inside $(\sim 1 \mathrm{~m})$ the lagoon where microbial matsare absent.

Fig. 11 TFE against TS (a) and TOC against TS (b). (a) "Pyrite line" represents the stoichiometric slope of pyrite. (b) Linear regression is applied to Core 3 only. Data from sediments below sulfur-oxidizing Beggiatoa microbial mats (at the edge of lagoon) are shown in red whereas blue symbols indicate sediment sampled further inside $(\sim 1 \mathrm{~m})$ the lagoon where microbial mats are absent.

Fig. $12 \delta^{34} \mathrm{~S}_{\text {pyrite }}$ as a function of TOC/TS ratio (a) and $\delta^{34} \mathrm{~S}_{\text {pyrite }}$ against $\delta^{13} \mathrm{C}_{\mathrm{TOC}}$ (b). On both plots, linear regressions are performed with all data. Data from sediments below sulfuroxidizing Beggiatoa microbial mats (at the edge of lagoon) are shown in red whereas blue symbols indicate sediment sampled further inside $(\sim 1 \mathrm{~m})$ the lagoon where microbial mats are absent.

\section{Notation}

The conventional delta notation is defined as follow:

$$
\delta^{13} \mathrm{C}, \delta^{18} \mathrm{O} \text { or } \delta^{34} \mathrm{~S}=\left(\frac{R_{\text {sample }}}{R_{\text {ref }}}-1\right) \times 1000(\%)
$$

With $R_{\text {sample }}$ is the isotope ratio of sample equal to ${ }^{13} \mathrm{C} /{ }^{12} \mathrm{C},{ }^{18} \mathrm{O} /{ }^{16} \mathrm{O}$ or ${ }^{34} \mathrm{~S} /{ }^{32} \mathrm{~S}$ and $R_{\text {ref }}$ referring to the international references Vienne PeeDee Belemnite (VDPB), Vienna Standard Mean Ocean Water (VSMOW) and Vienna Cañon Diablo Troilite (VCDT) for carbon, oxygen and sulfur, respectively.

The apparent sulfur isotope enrichment factor ${ }^{34} \varepsilon_{\text {net }}$ is calculated as follow: 


$$
{ }^{34} \varepsilon_{\text {net }}(\% 0)=\left({ }^{34} \alpha_{\text {net }}-1\right) \times 1000 \text { where }{ }^{34} \alpha_{\text {net }}=\frac{H_{2}{ }^{34} S / H_{2}{ }^{32} S}{{ }^{34} S_{4}^{2-} /{ }^{32} S_{4}^{2-}}
$$

\section{Acknowledgments}

This work was supported by the Institute of Ecology and Environmental Sciences (IEES). Artur Fugmann (Münster University), Jessy Toncin (UPMC), Magloire Mandeng-Yogo (IRD), Mercedes Mendez (IRD), Véronique Vaury (UPMC) and Lucie Courcot (ULCO) are acknowledged for their contribution in lab work. Omar Boudouma (UPMC) is acknowledged for his guidance during SEM. We are grateful for the comments and suggestions from two anonymous reviewers. Wei-Li Hong acknowledges the Research Council of Norway through its Centers of Excellence funding scheme, project number 223259, for financial support.

\section{Bibliography}

Aharon, P., Fu, B., 2000. Microbial sulfate reduction rates and sulfur and oxygen isotope fractionations at oil and gas seeps in deepwater Gulf of Mexico. Geochim. Cosmochim. Acta 64, 233-246. doi:10.1016/S0016-7037(99)00292-6

Aller, R.C., Madrid, V., Chistoserdov, A., Aller, J.Y., Heilbrun, C., 2010. Unsteady diagenetic processes and sulfur biogeochemistry in tropical deltaic muds: Implications for oceanic isotope cycles and the sedimentary record. Geochim. Cosmochim. Acta 74, 46714692. doi:10.1016/j.gca.2010.05.008

Antler, G., Turchyn, A.V., Herut, B., Davies, A., Rennie, V.C.F., Sivan, O., 2014. Sulfur and oxygen isotope tracing of sulfate driven anaerobic methane oxidation in estuarine sediments. Estuar. Coast. Shelf Sci. 142, 4-11. doi:10.1016/j.ecss.2014.03.001 
Antler, G., Turchyn, A.V., Herut, B., Sivan, O., 2015. A unique isotopic fingerprint of sulfatedriven anaerobic oxidation of methane. Geology G36688.1. doi:10.1130/G36688.1

Antler, G., Turchyn, A.V., Rennie, V., Herut, B., Sivan, O., 2013. Coupled sulfur and oxygen isotope insight into bacterial sulfate reduction in the natural environment. Geochim.

Cosmochim. Acta 118, 98-117. doi:10.1016/j.gca.2013.05.005

Appleby, P.G., 2001. Chronostratigraphic techniques in recent sediments, in: Last, W.M., Smol, J.P. (Eds.), Tracking Environmental Change Using Lake Sediments, Developments in Paleoenvironmental Research. Springer Netherlands, pp. 171-203. doi:10.1007/0-306-47669X_9

Berner, R.A., 1984. Sedimentary pyrite formation: An update. Geochim. Cosmochim. Acta 48, 605-615. doi:10.1016/0016-7037(84)90089-9

Berner, R.A., 1980. Early Diagenesis: A Theoretical Approach. Princeton University Press. Berner, R.A., Raiswell, R., 1983. Burial of organic carbon and pyrite sulfur in sediments over phanerozoic time: a new theory. Geochim. Cosmochim. Acta 47, 855-862. doi:10.1016/00167037(83)90151-5

Boetius, A., Ravenschlag, K., Schubert, C., Rickert, D., Widdel, F., Gieseke, A., Amann, R., Jørgensen, B., Witte, U., Pfannkuche, O., 2000. A marine microbial consortium apparently mediating anaerobic oxidation of methane. Nature 407, 623-626. doi:10.1038/35036572 Borges, A.V., 2003. Atmospheric $\mathrm{CO}_{2}$ flux from mangrove surrounding waters. Geophys. Res. Lett. 30. doi:10.1029/2003GL017143

Borowski, W.S., Paull, C.K., Ussler, W., 1999. Global and local variations of interstitial sulfate gradients in deep-water, continental margin sediments: Sensitivity to underlying methane and gas hydrates. Mar. Geol. 159, 131-154. doi:10.1016/S0025-3227(99)00004-3 
Böttcher, M.E., Bernasconi, S.M., Brumsack, H.-J., 1999. 32. Carbon, sulfur, and oxygen isotope geochemistry of interstitial waters from the western Mediterranien. Proceedings of the Ocean Drilling Program, Scientific Results, pp. 413-421.

Böttcher, M.E., Brumsack, H.-J., De Lange, G.J., 1998. Sulfate reduction and related stable isotope $\left({ }^{34} \mathrm{~S},{ }^{18} \mathrm{O}\right)$ variations in interstitial waters from the Eastern Mediterranean. Proceedings of the Ocean Drilling Program, Scientific Results, pp. 365-376.

Böttcher, M.E., Thamdrup, B., Gehre, M., Theune, A., 2005. ${ }^{34} \mathrm{~S} /{ }^{32} \mathrm{~S}$ and ${ }^{18} \mathrm{O} /{ }^{16} \mathrm{O}$ Fractionation During Sulfur Disproportionation by Desulfobulbus propionicus. Geomicrobiol. J. 22, 219-226. doi:10.1080/01490450590947751

Böttcher, M.E., Thamdrup, B., Vennemann, T.W., 2001. Oxygen and sulfur isotope fractionation during anaerobic bacterial disproportionation of elemental sulfur. Geochim. Cosmochim. Acta 65, 1601-1609. doi:10.1016/S0016-7037(00)00628-1 Bouillon, S., Borges, A.V., Castañeda-Moya, E., Diele, K., Dittmar, T., Duke, N.C., Kristensen, E., Lee, S.Y., Marchand, C., Middelburg, J.J., Rivera-Monroy, V.H., Smith, T.J., Twilley, R.R., 2008. Mangrove production and carbon sinks: A revision of global budget estimates. Glob. Biogeochem. Cycles 22, GB2013. doi:10.1029/2007GB003052 Bouillon, S., Dahdouh-Guebas, F., Rao, A.V.V.S., Koedam, N., Dehairs, F., 2003. Sources of organic carbon in mangrove sediments: variability and possible ecological implications. Hydrobiologia 495, 33-39. doi:10.1023/A:1025411506526

Breithaupt, J.L., Smoak, J.M., Smith, T.J., Sanders, C.J., Hoare, A., 2012. Organic carbon burial rates in mangrove sediments: Strengthening the global budget. Glob. Biogeochem. Cycles 26, GB3011. doi:10.1029/2012GB004375

Brunner, B., Bernasconi, S.M., Kleikemper, J., Schroth, M.H., 2005. A model for oxygen and sulfur isotope fractionation in sulfate during bacterial sulfate reduction processes. Geochim. Cosmochim. Acta 69, 4773-4785. doi:10.1016/j.gca.2005.04.017 
Canfield, D., 1989. Reactive iron in marine-sediments. Geochim. Cosmochim. Acta 53, 619632. doi:10.1016/0016-7037(89)90005-7

Canfield, D., Raiswell, R., Bottrell, S., 1992. The reactivity of sedimentary iron minerals toward sulfide. Am. J. Sci. 292, 659-683.

Canfield, D.E., 2001. Biogeochemistry of sulfur isotopes. Rev. Mineral. Geochem. 43, 607636.

Canfield, D.E., Boudreau, B.P., Mucci, A., Gundersen, J.K., 1998. The early diagenetic formation of organic sulfur in the sediments of Mangrove lake, Bermuda. Geochim.

Cosmochim. Acta 62, 767-781. doi:10.1016/S0016-7037(98)00032-5

Canfield, D.E., Raiswell, R., Westrich, J.T., Reaves, C.M., Berner, R.A., 1986. The use of chromium reduction in the analysis of reduced inorganic sulfur in sediments and shales. Chem. Geol. 54, 149-155. doi:10.1016/0009-2541(86)90078-1

Canfield, D.E., Thamdrup, B., 1996. Fate of elemental sulfur in an intertidal sediment. FEMS Microbiol. Ecol. 19, 95-103. doi:10.1111/j.1574-6941.1996.tb00202.x

Canfield, D.E., Thamdrup, B., 1994. The production of ${ }^{34}$ S-depleted sulfide during bacterial disproportionation of elemental sulfur. Science 266, 1973-1975.

doi:10.1126/science. 11540246

Chambers, L.A., Trudinger, P.A., 1979. Microbiological fractionation of stable sulfur isotopes: A review and critique. Geomicrobiol. J. 1, 249-293.

doi:10.1080/01490457909377735

Chuang, P.-C., Young, M.B., Dale, A.W., Miller, L.G., Herrera-Silveira, J.A., Paytan, A., 2016. Methane and sulfate dynamics in sediments from mangrove-dominated tropical coastal lagoons, Yucatán, Mexico. Biogeosciences 13, 2981-3001. doi:10.5194/bg-13-2981-2016 
Dale, A.W., Brüchert, V., Alperin, M., Regnier, P., 2009. An integrated sulfur isotope model for Namibian shelf sediments. Geochim. Cosmochim. Acta 73, 1924-1944.

doi:10.1016/j.gca.2008.12.015

Dale, A.W., Regnier, P., Knab, N.J., Jørgensen, B.B., Van Cappellen, P., 2008. Anaerobic oxidation of methane (AOM) in marine sediments from the Skagerrak (Denmark): II. Reaction-transport modeling. Geochim. Cosmochim. Acta 72, 2880-2894. doi:10.1016/j.gca.2007.11.039

Deusner, C., Holler, T., Arnold, G.L., Bernasconi, S.M., Formolo, M.J., Brunner, B., 2014. Sulfur and oxygen isotope fractionation during sulfate reduction coupled to anaerobic oxidation of methane is dependent on methane concentration. Earth Planet. Sci. Lett. 399, 6173. doi:10.1016/j.eps1.2014.04.047

Dittmar, T., Hertkorn, N., Kattner, G., Lara, R.J., 2006. Mangroves, a major source of dissolved organic carbon to the oceans. Glob. Biogeochem. Cycles 20, GB2570. doi:10.1029/2005GB002570

Donato, D.C., Kauffman, J.B., Murdiyarso, D., Kurnianto, S., Stidham, M., Kanninen, M., 2011. Mangroves among the most carbon-rich forests in the tropics. Nat. Geosci. 4, 293-297. doi:10.1038/ngeo1123

Farquhar, J., Canfield, D.E., Masterson, A., Bao, H., Johnston, D., 2008. Sulfur and oxygen isotope study of sulfate reduction in experiments with natural populations from Fællestrand, Denmark. Geochim. Cosmochim. Acta 72, 2805-2821. doi:10.1016/j.gca.2008.03.013 Farquhar, J., Johnston, D.T., Wing, B.A., Habicht, K.S., Canfield, D.E., Airieau, S., Thiemens, M.H., 2003. Multiple sulphur isotopic interpretations of biosynthetic pathways: implications for biological signatures in the sulphur isotope record. Geobiology 1, 27-36. doi:10.1046/j.1472-4669.2003.00007.x 
Fike, D.A., Bradley, A.S., Rose, C.V., 2015. Rethinking the Ancient Sulfur Cycle. Annu. Rev. Earth Planet. Sci. 43, 593-622. doi:10.1146/annurev-earth-060313-054802

Fossing, H., Gallardo, V.A., Jørgensen, B.B., Hüttel, M., Nielsen, L.P., Schulz, H., Canfield, D.E., Forster, S., Glud, R.N., Gundersen, J.K., Küver, J., Ramsing, N.B., Teske, A., Thamdrup, B., Ulloa, O., 1995. Concentration and transport of nitrate by the mat-forming sulphur bacterium Thioploca. Nature 374, 713-715. doi:10.1038/374713a0

Froelich, P.N., Klinkhammer, G.P., Bender, M.L., Luedtke, N.A., Heath, G.R., Cullen, D., Dauphin, P., Hammond, D., Hartman, B., Maynard, V., 1979. Early oxidation of organic matter in pelagic sediments of the eastern equatorial Atlantic: suboxic diagenesis. Geochim. Cosmochim. Acta 43, 1075-1090. doi:10.1016/0016-7037(79)90095-4

Fry, B., Hayes, J. m., 1984. Isotope effects associated with the anaerobic oxidation of sulfide by the purple photosynthetic bacterium, Chromatium vinosum. FEMS Microbiol. Lett. 22, 283-287. doi:10.1111/j.1574-6968.1984.tb00742.x

Fry, B., Ruf, W., Gest, H., Hayes, J.M., 1988. Sulfur isotope effects associated with oxidation of sulfide by $\mathrm{O}_{2}$ in aqueous solution. Chem. Geol. Isot. Geosci. Sect. 73, 205-210. doi:10.1016/0168-9622(88)90001-2

Furukawa, K., Wolanski, E., Mueller, H., 1997. Currents and sediment transport in mangrove sorests. Estuar. Coast. Shelf Sci. 44, 301-310. doi:10.1006/ecss.1996.0120

Giri, C., Ochieng, E., Tieszen, L.L., Zhu, Z., Singh, A., Loveland, T., Masek, J., Duke, N., 2011. Status and distribution of mangrove forests of the world using earth observation satellite data. Glob. Ecol. Biogeogr. 20, 154-159. doi:10.1111/j.1466-8238.2010.00584.x Goldhaber, M.B., Kaplan, I.R., 1980. Mechanisms of sulfur incorporation and isotope fractionation during early diagenesis in sediments of the gulf of California. Mar. Chem. 9, 95143. doi:10.1016/0304-4203(80)90063-8 
Gontharet, S., Crémière, A., Blanc-Valleron, M.-M., Sebilo, M., Gros, O., Laverman, A.M., Dessailly, D., 2016. Sediment characteristics and microbial mats in a marine mangrove, Manche-à-eau lagoon (Guadeloupe). J. Soils Sediments 1-12. doi:10.1007/s11368-016-15556

Grünke, S., Felden, J., Lichtschlag, A., Girnth, A.-C., De Beer, D., Wenzhöfer, F., Boetius, A., 2011. Niche differentiation among mat-forming, sulfide-oxidizing bacteria at cold seeps of the Nile Deep Sea Fan (Eastern Mediterranean Sea). Geobiology 9, 330-348. doi:10.1111/j.1472-4669.2011.00281.x

Guidi-Rontani, C., Jean, M.R.N., Gonzalez-Rizzo, S., Bolte-Kluge, S., Gros, O., 2014. Description of new filamentous toxic Cyanobacteria (Oscillatoriales) colonizing the sulfidic periphyton mat in marine mangroves. FEMS Microbiol. Lett. 359, 173-181. doi:10.1111/1574-6968.12551

Habicht, K.S., Canfield, D.E., 2001. Isotope fractionation by sulfate-reducing natural populations and the isotopic composition of sulfide in marine sediments. Geology 29, 555558. doi:10.1130/0091-7613(2001)029.0.CO;2

Habicht, K.S., Canfield, D.E., 1997. Sulfur isotope fractionation during bacterial sulfate reduction in organic-rich sediments. Geochim. Cosmochim. Acta 61, 5351-5361. doi:10.1016/S0016-7037(97)00311-6

Holmer, M., Kristensen, E., 1994. Coexistence of sulfate reduction and methane production in an organic-rich sediment. Mar. Ecol.-Prog. Ser. 107, 177-177.

Holmer, M., Kristensen, E., Banta, G., Hansen, K., Jensen, M.H., Bussawarit, N., 1994. Biogeochemical cycling of sulfur and iron in sediments of a south-east Asian mangrove, Phuket Island, Thailand. Biogeochemistry 26, 145-161. 
Holmkvist, L., Ferdelman, T.G., Jørgensen, B.B., 2011. A cryptic sulfur cycle driven by iron in the methane zone of marine sediment (Aarhus Bay, Denmark). Geochim. Cosmochim. Acta 75, 3581-3599. doi:10.1016/j.gca.2011.03.033

Hong, W.-L., Sauer, S., Panieri, G., Ambrose, W.G., James, R.H., Plaza-Faverola, A., Schneider, A., 2016. Removal of methane through hydrological, microbial, and geochemical processes in the shallow sediments of pockmarks along eastern Vestnesa Ridge (Svalbard). Limnol. Oceanogr., 61: S324-S343 doi:10.1002/lno.10299

Howarth, R.W., Jørgensen, B.B., 1984. Formation of ${ }^{35}$ S-labelled elemental sulfur and pyrite in coastal marine sediments (Limfjorden and Kysing Fjord, Denmark) during short-term ${ }^{35} \mathrm{SO}_{4}{ }^{2-}$ reduction measurements. Geochim. Cosmochim. Acta 48, 1807-1818. doi:10.1016/0016-7037(84)90034-6

Imbert, D., Labbé, P., Rousteau, A., 1996. Hurricane damage and forest structure in Guadeloupe, French West Indies. J. Trop. Ecol. 12, 663-680.

doi:10.1017/S026646740000986X

Jean, M.R.N., Gonzalez-Rizzo, S., Gauffre-Autelin, P., Lengger, S.K., Schouten, S., Gros, O., 2015. Two new Beggiatoa species inhabiting marine mangrove sediments in the Caribbean.

PLoS ONE 10, e0117832. doi:10.1371/journal.pone.0117832

Jennerjahn, T.C., Ittekkot, V., 2002. Relevance of mangroves for the production and deposition of organic matter along tropical continental margins. Naturwissenschaften $89,23-$ 30.

Johnston, D.T., Farquhar, J., Wing, B.A., Kaufman, A.J., Canfield, D.E., Habicht, K.S., 2005. Multiple sulfur isotope fractionations in biological systems: A case study with sulfate reducers and sulfur disproportionators. Am. J. Sci. 305, 645-660. doi:10.2475/ajs.305.6-8.645 Jørgensen, B.B., 1982. Mineralization of organic matter in the sea bed-the role of sulphate reduction. Nature 296, 643-645. doi:10.1038/296643a0 
Jørgensen, B.B., JØrgensen, B.B., Parkes, R.J., 2010. Role of sulfate reduction and methane production by organic carbon degradation in eutrophic fjord sediments (Limfjorden, Denmark). Limnol. Oceanogr. 55, 1338-1352. doi:10.4319/1o.2010.55.3.1338

Kaplan, I.R., Rittenberg, S.C., 1964. Microbiological Fractionation of Sulphur Isotopes. J. Gen. Microbiol. 34, 195-212. doi:10.1099/00221287-34-2-195

Kristensen, E., Bouillon, S., Dittmar, T., Marchand, C., 2008. Organic carbon dynamics in mangrove ecosystems: A review. Aquat. Bot. 89, 201-219. doi:10.1016/j.aquabot.2007.12.005

Kunzmann, M., Bui, T.H., Crockford, P.W., Halverson, G.P., Scott, C., Lyons, T.W., Wing, B.A., 2017. Bacterial sulfur disproportionation constrains timing of Neoproterozoic oxygenation. Geology G38602.1. doi:10.1130/G38602.1

Lallier-Verges, E., Perrussel, B.P., Disnar, J.-R., Baltzer, F., 1998. Relationships between environmental conditions and the diagenetic evolution of organic matter derived from higher plants in a modern mangrove swamp system (Guadeloupe, French West Indies). Org.

Geochem. 29, 1663-1686. doi:10.1016/S0146-6380(98)00179-X

Lamb, A.L., Wilson, G.P., Leng, M.J., 2006. A review of coastal palaeoclimate and relative sea-level reconstructions using $\delta^{13} \mathrm{C}$ and $\mathrm{C} / \mathrm{N}$ ratios in organic material. Earth-Sci. Rev. 75, 29-57. doi:10.1016/j.earscirev.2005.10.003

Leavitt, W.D., Halevy, I., Bradley, A.S., Johnston, D.T., 2013. Influence of sulfate reduction rates on the Phanerozoic sulfur isotope record. Proc. Natl. Acad. Sci. 110, 11244-11249. doi:10.1073/pnas. 1218874110

Madrid, V.M., Aller, R.C., Aller, J.Y., Chistoserdov, A.Y., 2006. Evidence of the activity of dissimilatory sulfate-reducing prokaryotes in nonsulfidogenic tropical mobile muds. FEMS Microbiol. Ecol. 57, 169-181. doi:10.1111/j.1574-6941.2006.00123.x 
Maltby, J., Sommer, S., Dale, A.W., Treude, T., 2016. Microbial methanogenesis in the sulfate-reducing zone of surface sediments traversing the Peruvian margin. Biogeosciences 13, 283-299. doi:10.5194/bg-13-283-2016

Mantran, M., Hamparian, R., Bouchereau, J.-L., 2009. Géomorphologie et hydrologie de la lagune de la Manche-à-Eau (Guadeloupe, Antilles françaises). Géomorphologie Relief Process. Environ. 199-210. doi:10.4000/geomorphologie.7606

Mariotti, A., Germon, J., Hubert, P., Kaiser, P., Letolle, R., Tardieux, A., Tardieux, P., 1981. Experimental determination of nitrogen kinetic isotope fractionation: some principles; illustration for the denitrification and nitrification processes. Plant Soil 62, 413-430. McKay, L.J., MacGregor, B.J., Biddle, J.F., Albert, D.B., Mendlovitz, H.P., Hoer, D.R., Lipp, J.S., Lloyd, K.G., Teske, A.P., 2012. Spatial heterogeneity and underlying geochemistry of phylogenetically diverse orange and white Beggiatoa mats in Guaymas Basin hydrothermal sediments. Deep Sea Res. Part Oceanogr. Res. Pap. 67, 21-31. doi:10.1016/j.dsr.2012.04.011 McKee, K.L., Mendelssohn, I.A., Hester, M.W., 1988. Reexamination of Pore Water Sulfide Concentrations and Redox Potentials Near the Aerial Roots of Rhizophora mangle and Avicennia germinans. Am. J. Bot. 75, 1352-1359. doi:10.2307/2444458

Middelburg, J.J., 1989. A simple rate model for organic matter decomposition in marine sediments. Geochim. Cosmochim. Acta 53, 1577-1581. doi:10.1016/0016-7037(89)90239-1 Müller, P.J., Suess, E., 1979. Productivity, sedimentation rate, and sedimentary organic matter in the oceans - I. Organic carbon preservation. Deep Sea Res. Part Oceanogr. Res. Pap. 26, 1347-1362. doi:10.1016/0198-0149(79)90003-7

Oremland, R.S., Marsh, L.M., Polcin, S., 1982. Methane production and simultaneous sulphate reduction in anoxic, salt marsh sediments. Nature 296, 143-145.

doi:10.1038/296143a0 
Oremland, R.S., Polcin, S., 1982. Methanogenesis and Sulfate Reduction: Competitive and Noncompetitive Substrates in Estuarine Sediments. Appl. Environ. Microbiol. 44, 1270-1276. Peck, H.D., 1961. Enzymatic Basis for Assimilatory and Dissimilatory Sulfate Reduction. J. Bacteriol. 82, 933-939.

Peck, H.D., 1959. The ATP-dependent reduction of sulfate with hydrogen in extracts of Desulfovibrio desulfuricans. Proc. Natl. Acad. Sci. 45, 701-708.

Pellerin, A., Bui, T.H., Rough, M., Mucci, A., Canfield, D.E., Wing, B.A., 2015. Massdependent sulfur isotope fractionation during reoxidative sulfur cycling: A case study from Mangrove Lake, Bermuda. Geochim. Cosmochim. Acta 149, 152-164. doi:10.1016/j.gca.2014.11.007

Price, F.T., Shieh, Y.N., 1979. Fractionation of sulfur isotopes during laboratory synthesis of pyrite at low temperatures. Chem. Geol. 27, 245-253. doi:10.1016/0009-2541(79)90042-1 Raven, M.R., Sessions, A.L., Fischer, W.W., Adkins, J.F., 2016. Sedimentary pyrite $\delta 34$ S differs from porewater sulfide in Santa Barbara Basin: Proposed role of organic sulfur. Geochim. Cosmochim. Acta 186, 120-134. doi:10.1016/j.gca.2016.04.037

Reeburgh, W.S., 2007. Oceanic Methane Biogeochemistry. Chem. Rev. 107, 486-513. doi:10.1021/cr050362v

Rees, C.E., 1973. A steady-state model for sulphur isotope fractionation in bacterial reduction processes. Geochim. Cosmochim. Acta 37, 1141-1162. doi:10.1016/0016-7037(73)90052-5 Rickard, D., 1997. Kinetics of pyrite formation by the H2S oxidation of iron (II) monosulfide in aqueous solutions between 25 and $125^{\circ} \mathrm{C}$ : The rate equation. Geochim. Cosmochim. Acta 61, 115-134. doi:10.1016/S0016-7037(96)00321-3

Rudnicki, M.D., Elderfield, H., Spiro, B., 2001. Fractionation of sulfur isotopes during bacterial sulfate reduction in deep ocean sediments at elevated temperatures. Geochim. Cosmochim. Acta 65, 777-789. doi:10.1016/S0016-7037(00)00579-2 
Sanders, C.J., Eyre, B.D., Santos, I.R., Machado, W., Luiz-Silva, W., Smoak, J.M., Breithaupt, J.L., Ketterer, M.E., Sanders, L., Marotta, H., Silva-Filho, E., 2014. Elevated rates of organic carbon, nitrogen, and phosphorus accumulation in a highly impacted mangrove wetland. Geophys. Res. Lett. 41, 2014GL059789. doi:10.1002/2014GL059789

Schmidt, S., Deckker, P.D., 2015. Present-day sedimentation rates on the southern and southeastern Australian continental margins. Aust. J. Earth Sci. 62, 143-150. doi:10.1080/08120099.2015.1014846

Sim, M.S., Ono, S., Donovan, K., Templer, S.P., Bosak, T., 2011. Effect of electron donors on the fractionation of sulfur isotopes by a marine Desulfovibrio sp. Geochim. Cosmochim. Acta 75, 4244-4259. doi:10.1016/j.gca.2011.05.021

Sinninghe Damste, J.S., De Leeuw, J.W., 1990. Analysis, structure and geochemical significance of organically-bound sulphur in the geosphere: State of the art and future research. Org. Geochem., Proceedings of the 14th International Meeting on Organic Geochemistry 16, 1077-1101. doi:10.1016/0146-6380(90)90145-P Steefel, C.I., 2009. CrunchFlow. Softw. Model. Multicomponent React. Flow Transp. User's Man. Lawrence Berkeley Natl. Lab. Berkeley USA.

Thamdrup, B., Finster, K., Hansen, J.W., Bak, F., 1993. Bacterial disproportionation of elemental sulfur coupled to chemical reduction of iron or manganese. Appl. Environ. Microbiol. 59, 101-108.

Thamdrup, B., Fossing, H., Jørgensen, B.B., 1994. Manganese, iron and sulfur cycling in a coastal marine sediment, Aarhus bay, Denmark. Geochim. Cosmochim. Acta 58, 5115-5129. doi:10.1016/0016-7037(94)90298-4 Turchyn, A.V., Sivan, O., Schrag, D.P., 2006. Oxygen isotopic composition of sulfate in deep sea pore fluid: evidence for rapid sulfur cycling. Geobiology 4, 191-201. doi:10.1111/j.14724669.2006.00079.x 
Weber, H.S., Thamdrup, B., Habicht, K.S., 2016. High sulfur isotope fractionation associated with anaerobic oxidation of methane in a low sulfate, iron rich environment. Microbiol. Chem. Geomicrobiol. 4, 61. doi:10.3389/feart.2016.00061

Wilkin, R.T., Barnes, H.L., 1996. Pyrite formation by reactions of iron monosulfides with dissolved inorganic and organic sulfur species. Geochim. Cosmochim. Acta 60, 4167-4179. doi:10.1016/S0016-7037(97)81466-4

Wing, B.A., Halevy, I., 2014. Intracellular metabolite levels shape sulfur isotope fractionation during microbial sulfate respiration. Proc. Natl. Acad. Sci. 111, 18116-18125. doi:10.1073/pnas.1407502111

Wortmann, U.G., Bernasconi, S.M., Böttcher, M.E., 2001. Hypersulfidic deep biosphere indicates extreme sulfur isotope fractionation during single-step microbial sulfate reduction. Geology 29, 647-650. doi:10.1130/0091-7613(2001)029<0647:HDBIES>2.0.CO;2 Yao, W., Millero, F.J., 1996. Oxidation of hydrogen sulfide by hydrous Fe(III) oxides in seawater. Mar. Chem. 52, 1-16. doi:10.1016/0304-4203(95)00072-0

Zerkle, A.L., Farquhar, J., Johnston, D.T., Cox, R.P., Canfield, D.E., 2009. Fractionation of multiple sulfur isotopes during phototrophic oxidation of sulfide and elemental sulfur by a green sulfur bacterium. Geochim. Cosmochim. Acta 73, 291-306.

doi:10.1016/j.gca.2008.10.027

Zerkle, A.L., Jones, D.S., Farquhar, J., Macalady, J.L., 2016. Sulfur isotope values in the sulfidic Frasassi cave system, central Italy: A case study of a chemolithotrophic S-based ecosystem. Geochim. Cosmochim. Acta 173, 373-386. doi:10.1016/j.gca.2015.10.028 

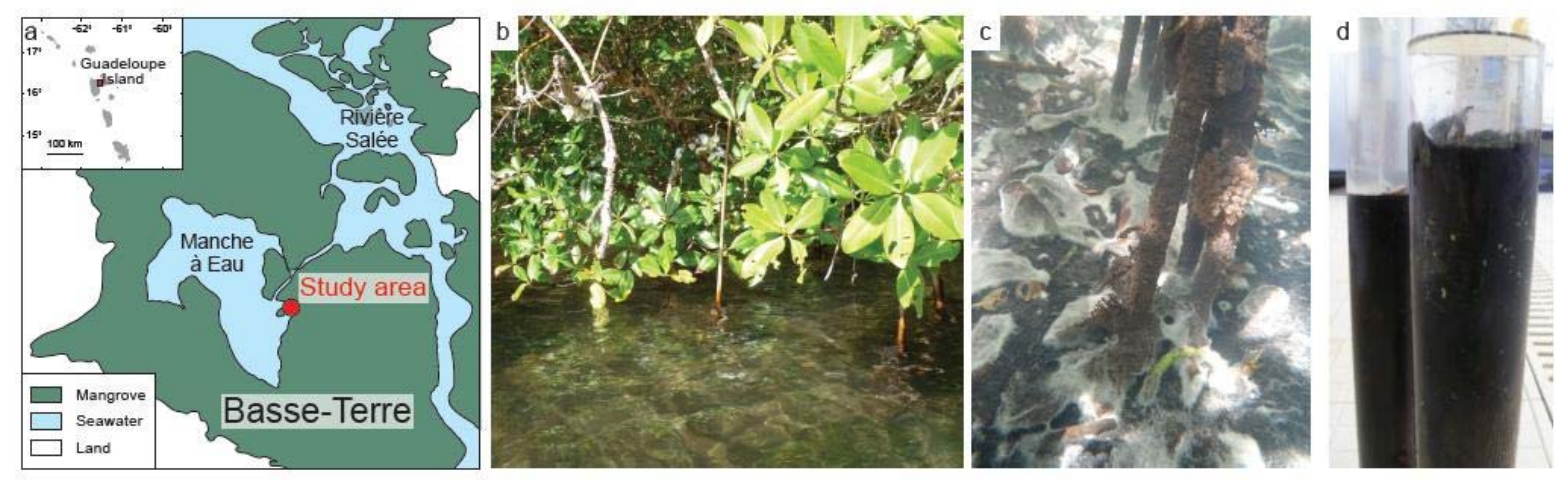

Figure 1 


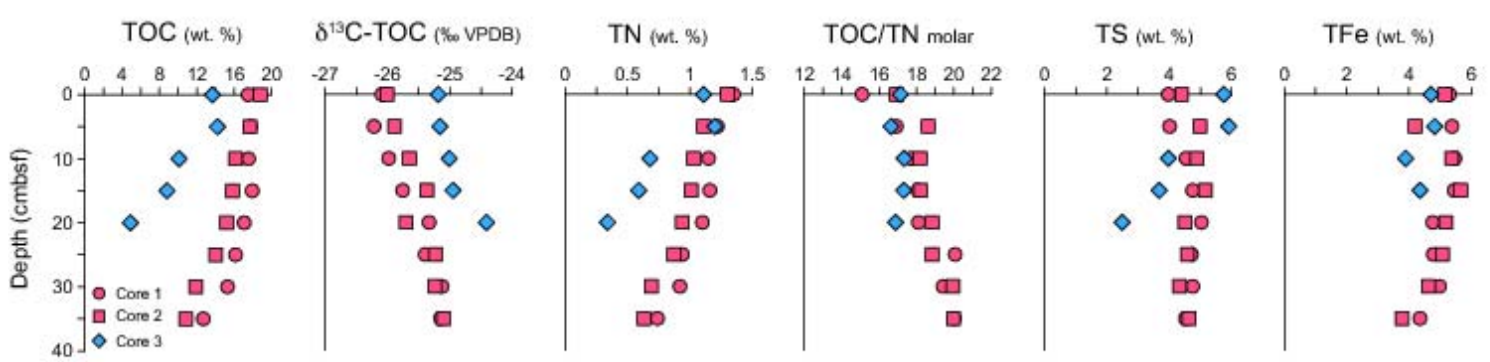

Fig.2 

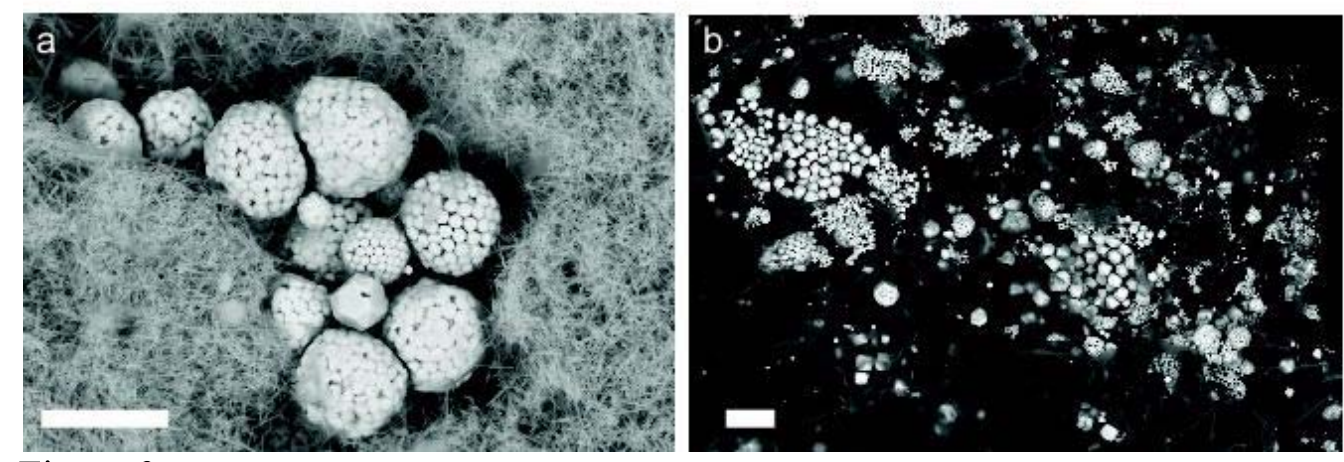

Figure 3 


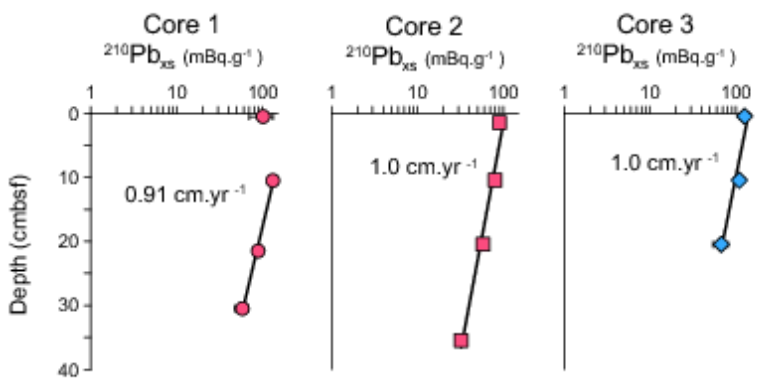

Fig. 4 


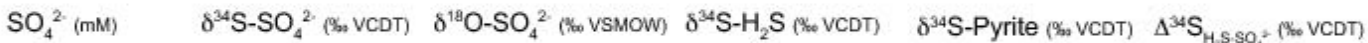
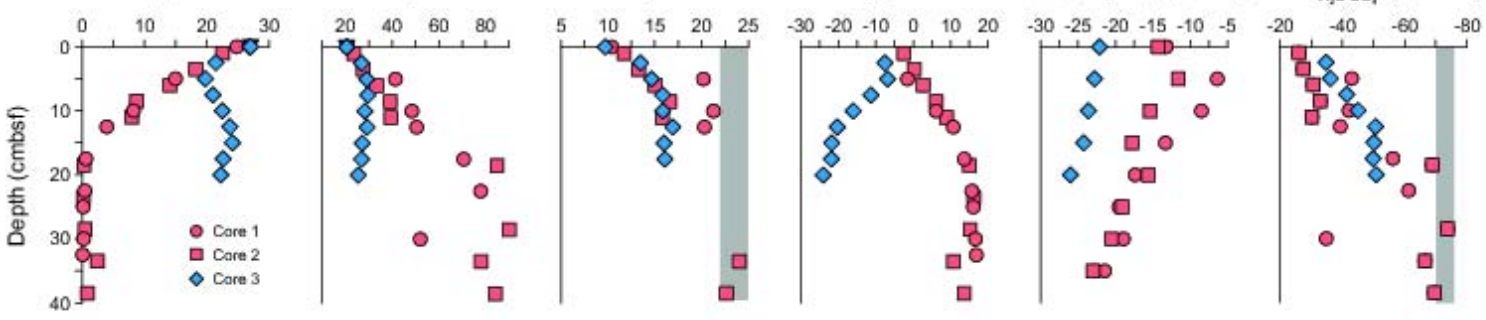

Fig. 5 


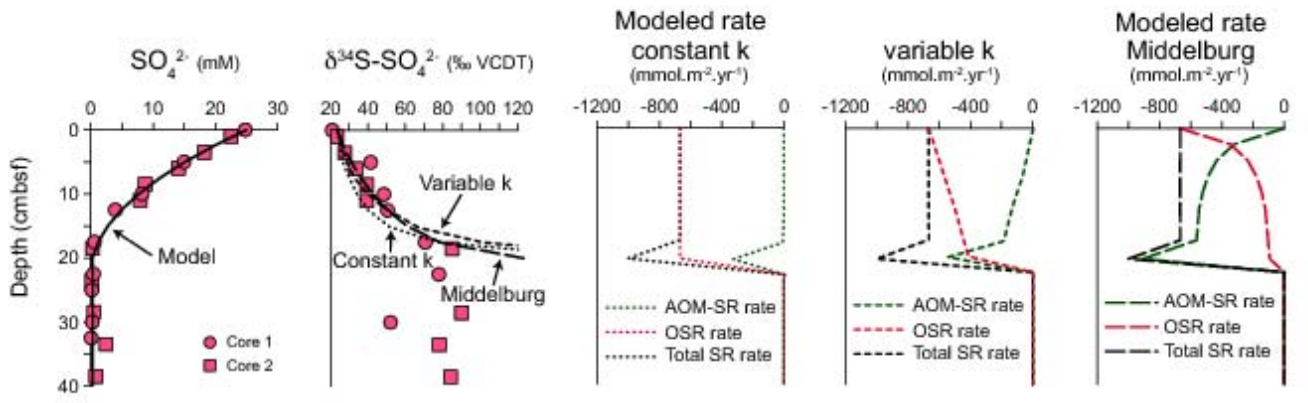

Fig. 6 


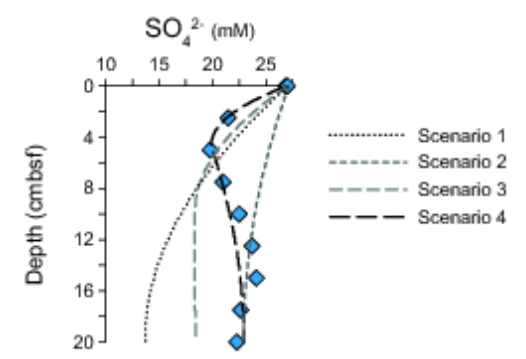

Fig. 7 


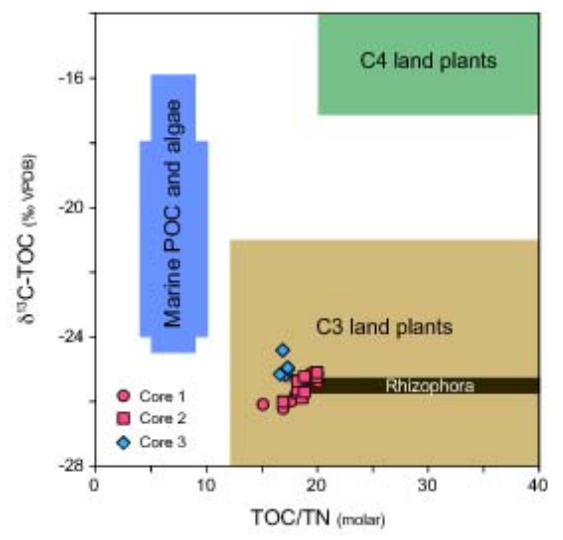

Fig. 8 


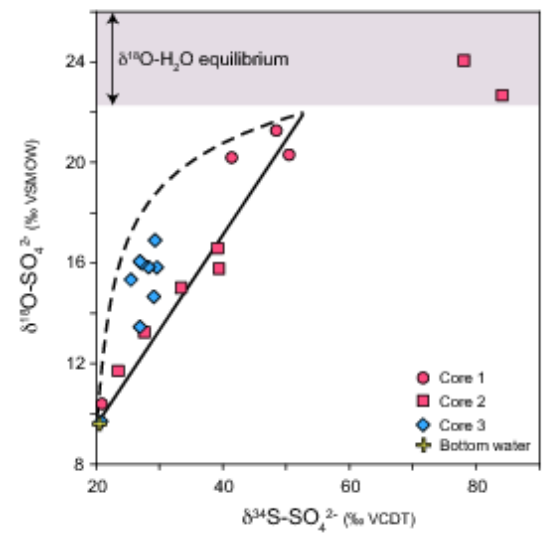

Fig. 9 


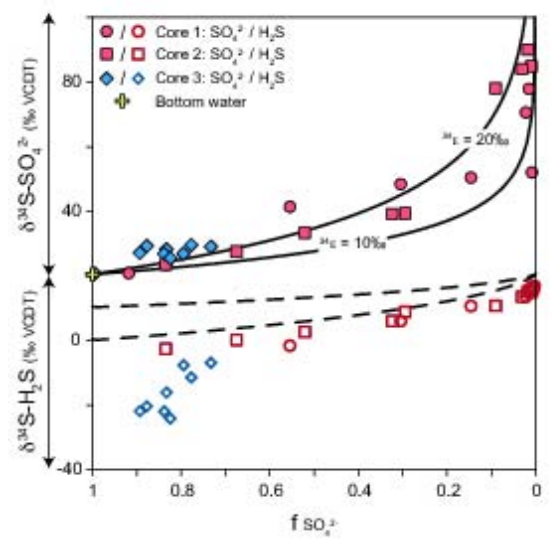

Fig. 10 

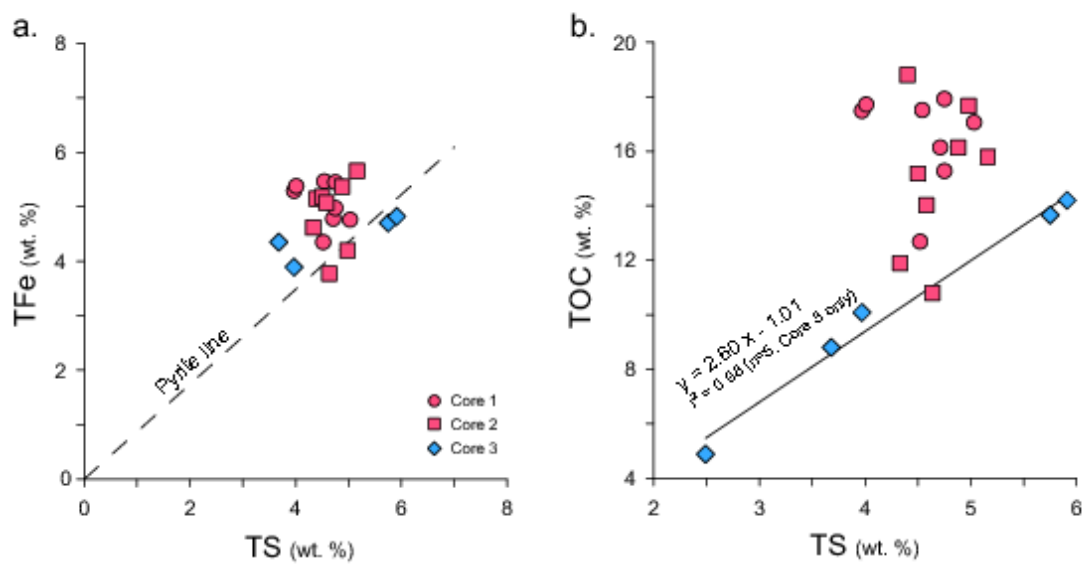

Fig.11 

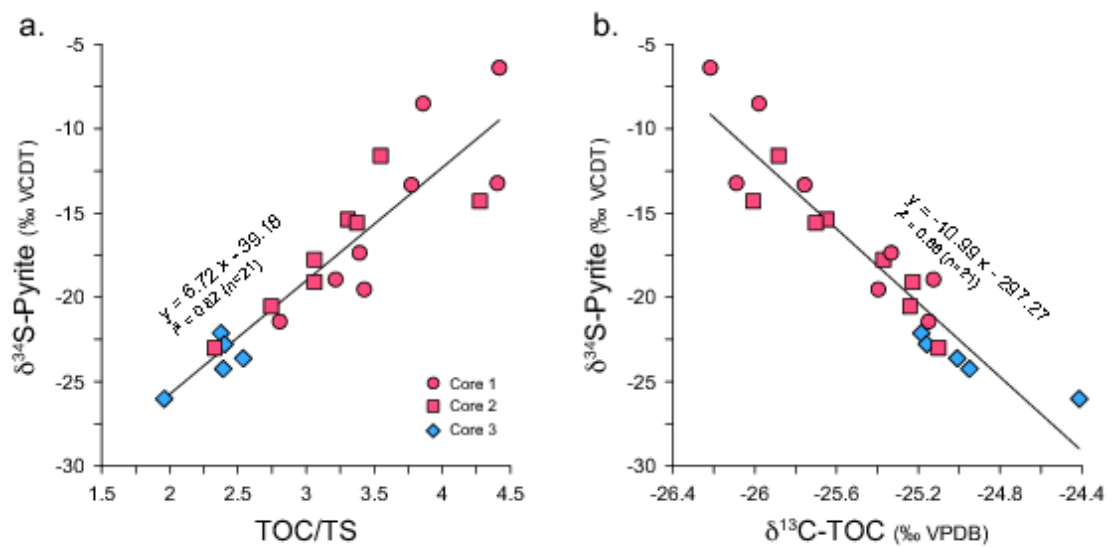

Fig.12 


\begin{tabular}{|c|c|c|c|c|c|c|c|c|c|}
\hline & $\begin{array}{l}\text { Depth } \\
\text { (cmbsf) }\end{array}$ & $\begin{array}{c}\text { TOC } \\
\text { (wt. \%) }\end{array}$ & $\begin{array}{l}\delta^{13} \mathrm{C}-\mathrm{TOC} \\
\text { (\%o VPDB) }\end{array}$ & $\begin{array}{c}\mathrm{N} \\
\text { (wt. \%) }\end{array}$ & $\underset{\text { (molar) }}{\mathrm{C} / \mathrm{N}}$ & $\begin{array}{c}\mathrm{TFe} \\
\text { (wt. \%) }\end{array}$ & $\begin{array}{c}\text { TS } \\
\text { (wt. \%) }\end{array}$ & $\begin{array}{l}\text { TOC/TS } \\
\text { (wt./wt.) }\end{array}$ & $\begin{array}{l}\delta^{34} \text { S-CRS } \\
\text { (\%o VCDT) }\end{array}$ \\
\hline \multicolumn{10}{|l|}{ Core 1} \\
\hline & 0 & 17.5 & -26.1 & 1.4 & 15.1 & 5.3 & 4.0 & 4.4 & -13.2 \\
\hline & 5 & 17.7 & -26.2 & 1.2 & 16.9 & 5.4 & 4.0 & 4.4 & -6.4 \\
\hline & 10 & 17.5 & -26.0 & 1.2 & 17.7 & 5.5 & 4.5 & 3.9 & -8.5 \\
\hline & 15 & 17.9 & -25.8 & 1.2 & 18.1 & 5.5 & 4.8 & 3.8 & -13.3 \\
\hline & 20 & 17.1 & -25.3 & 1.1 & 18.1 & 4.8 & 5.0 & 3.4 & -17.4 \\
\hline & 25 & 16.1 & -25.4 & 0.9 & 20.1 & 4.8 & 4.7 & 3.4 & -19.5 \\
\hline & 30 & 15.3 & -25.1 & 0.9 & 19.4 & 5.0 & 4.8 & 3.2 & -18.9 \\
\hline & 35 & 12.7 & -25.1 & 0.7 & 20.0 & 4.4 & 4.5 & 2.8 & -21.4 \\
\hline \multicolumn{10}{|l|}{ Core 2} \\
\hline & 0 & 18.8 & -26.0 & 1.3 & 16.9 & 5.1 & 4.4 & 4.3 & -14.3 \\
\hline & 5 & 17.7 & -25.9 & 1.1 & 18.6 & 4.2 & 5.0 & 3.5 & -11.6 \\
\hline & 10 & 16.1 & -25.6 & 1.0 & 18.2 & 5.4 & 4.9 & 3.3 & -15.4 \\
\hline & 15 & 15.8 & -25.4 & 1.0 & 18.2 & 5.7 & 5.2 & 3.1 & -17.8 \\
\hline & 20 & 15.2 & -25.7 & 0.9 & 18.8 & 5.2 & 4.5 & 3.4 & -15.6 \\
\hline & 25 & 14.0 & -25.2 & 0.9 & 18.8 & 5.1 & 4.6 & 3.1 & -19.1 \\
\hline & 30 & 11.9 & -25.2 & 0.7 & 19.9 & 4.6 & 4.3 & 2.7 & -20.5 \\
\hline & 35 & 10.8 & -25.1 & 0.6 & 20.0 & 3.8 & 4.6 & 2.3 & -23.0 \\
\hline \multicolumn{10}{|l|}{ Core 3} \\
\hline & 0 & 13.7 & -25.2 & 1.1 & 17.1 & 4.7 & 5.8 & 2.4 & -22.1 \\
\hline & 5 & 14.2 & -25.2 & 1.2 & 16.6 & 4.8 & 5.9 & 2.4 & -22.8 \\
\hline & 10 & 10.1 & -25.0 & 0.7 & 17.3 & 3.9 & 4.0 & 2.5 & -23.6 \\
\hline & 15 & 8.8 & -24.9 & 0.6 & 17.3 & 4.4 & 3.7 & 2.4 & -24.2 \\
\hline & 20 & 4.9 & -24.4 & 0.3 & 16.9 & - & 2.5 & 2.0 & -26.0 \\
\hline
\end{tabular}

Table 1. Sediments geochemistry. 


\begin{tabular}{lcccc}
\hline & Sed. rate & \multicolumn{2}{c}{ TOC $(\mathbf{w t}$ \%) } & TOC acc. $\left(\mathbf{g O C} \cdot \mathbf{m}^{\mathbf{- 2}} \cdot \mathbf{y r}^{-\mathbf{1}}\right.$ ) \\
& (cm/yr) & min. & max. & avg. \pm 2s \\
\hline Core 1 & 0.91 & 12.7 & 17.9 & $396 \pm 111$ \\
Core 2 & 1 & 10.8 & 18.8 & $386 \pm 79$ \\
Core 3 & 1 & 4.9 & 14.2 & $199 \pm 35$ \\
\hline
\end{tabular}

Table 2. Integrated rates of TOC accumulation (TOC acc.). 


\begin{tabular}{|c|c|c|c|c|c|}
\hline & $\begin{array}{c}\text { Depth } \\
\text { (cmbsf) }\end{array}$ & $\begin{array}{l}\mathrm{SO}_{4}{ }^{2-} \\
(\mathrm{mM})\end{array}$ & $\begin{array}{l}\delta^{34} \mathrm{~S} \mathrm{SO}_{4}{ }^{2-} \\
(\% \circ \mathrm{VCDT})\end{array}$ & $\begin{array}{l}\delta^{18} \mathrm{O}^{-S}{ }_{4}{ }^{2-} \\
(\% \circ \mathrm{VSMOW})\end{array}$ & $\begin{array}{c}\delta^{34} \mathrm{~S}-\mathrm{H}_{2} \mathrm{~S} \\
\text { (\%o VCDT) }\end{array}$ \\
\hline \multicolumn{6}{|l|}{ Core 1} \\
\hline & 0 & 24.8 & 20.9 & 10.4 & - \\
\hline & 5 & 15.0 & 41.4 & 20.2 & -1.6 \\
\hline & 10 & 8.2 & 48.5 & 21.3 & 6.1 \\
\hline & 12.5 & 3.9 & 50.5 & 20.3 & 10.7 \\
\hline & 17.5 & 0.6 & 70.6 & - & 13.6 \\
\hline & 22.5 & 0.4 & 77.9 & - & 15.7 \\
\hline & 25 & 0.2 & - & - & 16.1 \\
\hline & 30 & 0.2 & 52.1 & - & 16.6 \\
\hline & 32.5 & 0.1 & - & - & 16.9 \\
\hline \multicolumn{6}{|l|}{ Core 2} \\
\hline & 1 & 22.5 & 23.5 & 11.7 & -2.5 \\
\hline & 3.5 & 18.2 & 27.6 & 13.3 & 0.2 \\
\hline & 6 & 14.1 & 33.4 & 15.0 & 2.7 \\
\hline & 8.5 & 8.7 & 39.2 & 16.6 & 6.1 \\
\hline & 11 & 8.0 & 39.4 & 15.8 & 8.9 \\
\hline & 18.5 & 0.3 & 84.9 & - & 15.0 \\
\hline & 23.5 & 0.2 & - & - & 16.2 \\
\hline & 28.5 & 0.5 & 90.0 & - & 15.2 \\
\hline & 33.5 & 2.4 & 78.1 & 24.1 & 10.8 \\
\hline & 38.5 & 0.8 & 84.1 & 22.7 & 13.6 \\
\hline \multicolumn{6}{|l|}{ Core 3} \\
\hline & 0 & 26.9 & 20.8 & 9.7 & - \\
\hline & 2.5 & 21.5 & 26.9 & 13.5 & -7.6 \\
\hline & 5 & 19.8 & 29.1 & 14.7 & -6.8 \\
\hline & 7.5 & 21.0 & 29.6 & 15.8 & -11.3 \\
\hline & 10 & 22.5 & 28.3 & 15.8 & -16.0 \\
\hline & 12.5 & 23.7 & 29.3 & 16.9 & -20.3 \\
\hline & 15 & 24.1 & 27.2 & 16.0 & -21.8 \\
\hline & 17.5 & 22.6 & 26.9 & 16.1 & -21.9 \\
\hline & 20 & 22.3 & 25.5 & 15.3 & -24.1 \\
\hline Bottom water & - & 27.5 & 20.5 & 9.6 & - \\
\hline
\end{tabular}

Table 3. Porewater and bottom water geochemistry 